\title{
7. QUANTITATIVE CALCAREOUS NANNOFOSSIL BIOSTRATIGRAPHY OF PLIOCENE AND PLEISTOCENE SEDIMENTS FROM THE ERATOSTHENES SEAMOUNT REGION IN THE EASTERN MEDITERRANEAN ${ }^{1}$
}

\author{
T. Scott Staerker ${ }^{2,3}$
}

\begin{abstract}
Quantitative methods were used to document the abundance patterns of selected Pleistocene and Pliocene calcareous nannofossil species from four Ocean Drilling Program sites in the Eratosthenes Seamount region of the Eastern Mediterranean. Results show that many similarities exist between the species abundance patterns reported in this study and the abundance patterns from other geologic sequences in the Western and Central Mediterranean. Unconformities, likely associated with Pleistocene tectonic movement of the subducting Eratosthenes Seamount, limit the correlation of some biostratigraphic events. Despite the limitations caused by local tectonic erosion at Sites 965, 966, and 968, the geologic section recovered from Site 967 appears minimally affected and presents a high-resolution reference section for the Eastern Mediterranean. Three biostratigraphic events are proposed to refine correlation of the Pliocene geologic sections in the Eastern Mediterranean.
\end{abstract}

\section{INTRODUCTION}

Ocean Drilling Program (ODP) Leg 160 drilled holes at 11 sites in the Central and Eastern Mediterranean Sea. This study details the quantitatively derived abundance patterns of selected Pleistocene and Pliocene calcareous nannofossil species observed in samples collected from four of the Leg 160 sites.

Sites 965, 966, 967, and 968 were drilled along a south-to-north transect across the Eratosthenes Seamount in the Eastern Mediterranean (Fig. 1). The sedimentary cover on the Eratosthenes Seamount can be generally divided into three lithologic units: (1) Pleistocene through Pliocene nannofossil and foraminiferal oozes that contain numerous sapropel layers, (2) Miocene reefal carbonates devoid of planktonic microfossils, and (3) middle Eocene and Upper Cretaceous chalks, which contain numerous, albeit poorly preserved, microfossil assemblages (Emeis, Robertson, Richter, et al., 1996). The Pleistocene and Pliocene sediments collected from the Eratosthenes cores reflect a history of pelagic and hemipelagic sedimentation in a tectonically active depositional environment. In each hole studied, incomplete geologic sections that contain unconformities are evidenced from missing biostratigraphic zones or unrealistically compressed zones. The lack of synchroneity in the unconformities among holes suggests that local erosion related to faulting and slope failure along the flanks of the subducting seamount has likely resulted in the apparent hiatuses.

Previous studies have proposed Neogene Mediterranean zonation schemes (Schmidt, 1973; Müller, 1978; Ellis and Lohman, 1979; Raffi and Rio, 1979; and Rio et al., 1990). Other studies have used quantitative methods to collect species abundance data from geologic sections in the Central and Western Mediterranean and graphically display the abundance patterns of significant nannofossil species (Driever, 1981, 1988; Rio, 1982; Rio et al., 1990; Channell et al., 1992; Sprovieri, 1993; and Castradori, 1993). This study follows the zonation scheme and quantitative methods of Rio et al. (1990) to document the abundance patterns of selected species collected from the Eratosthenes Seamount region of the Eastern Mediterranean. The primary focus of this study is on the biostratigraphic applications of the

${ }^{1}$ Robertson, A.H.F., Emeis, K.-C., Richter, C., and Camerlenghi, A. (Eds.), 1998. Proc. ODP Sci. Results, 160: College Station, TX (Ocean Drilling Program).

${ }^{2}$ Texas Microscopy, 4812 Hanover Drive, Flower Mound, TX 75028, U.S.A

${ }^{3}$ Present address: BP Exploration, PO Box 4587, Houston, TX 77210-4857, U.S.A. staer1@airmail.net observed species abundance trends to determine if biostratigraphic events documented from the Central and Western Mediterranean are present in the Eratosthenes region, and to determine if events not currently used in the Rio et al. (1990) zonation scheme are useful for correlation in sections throughout the Mediterranean. A discussion of the species abundance trends is included to emphasize similarities and differences between abundance patterns from the Eratosthenes Seamount sites and the abundance patterns presented from earlier studies of the Tyrrhenian Sea (Rio et al., 1990), Monte San Nicola section in Southern Sicily (Channell et al., 1992; Driever, 1988), Ionian Sea (Castradori, 1993), Aghios Vlassios and Finikia sections in Crete (Driever, 1988), and Singa section in Calabria (Driever, 1988).

Through comparison of the Eratosthenes sites to other geologic sections, this study suggests that many of the abundance characteristics of Pliocene and Pleistocene species that are used as biostratigraphic markers in both the Central and Western Mediterranean are consistent markers in the Eratosthenes region of the Eastern Mediterranean. Additionally, the study provides further evidence that abundance characteristics of three discoasters, currently unused as zonal markers in the Rio et al. (1990) zonal scheme, are consistent events

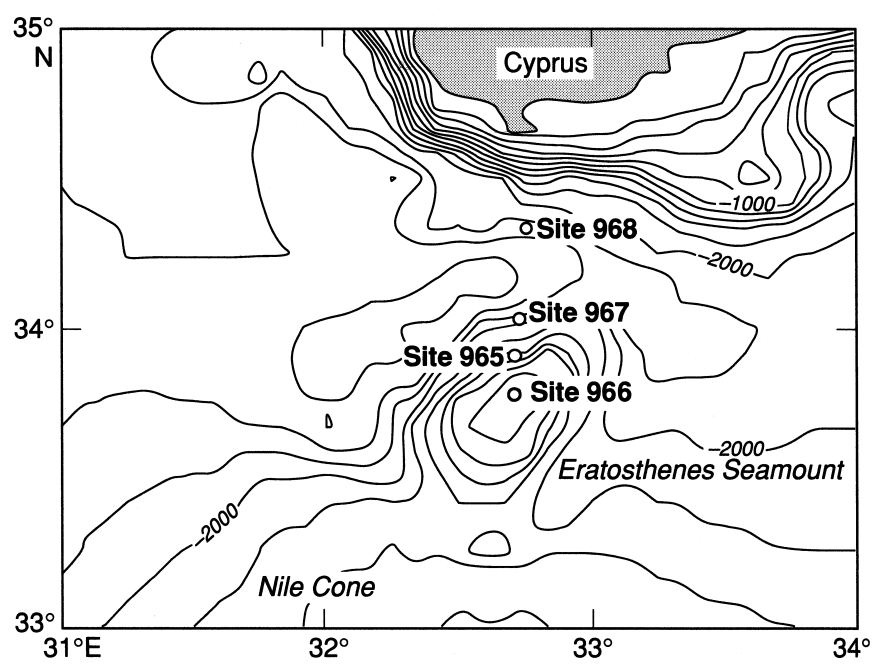

Figure 1. Location of drill sites along a south-to-north transect above the Eratosthenes Seamount in the Eastern Mediterranean. Bathymetry is in meters. 
that can used to further subdivide Pliocene biostratigraphy throughout the Mediterranean.

\section{SCIENTIFIC OBJECTIVES, METHODS, AND BIOSTRATIGRAPHIC ZONATIONS}

With the exception of the shallow-water carbonates at Site 965 , all of the cores recovered from Leg 160 sites were conducive to nannofossil analysis. A total of 1275 samples from the Eratosthenes Transect (Sites 965-968) were analyzed during this postcruise nannofossil project. Samples were collected aboard ship by members of the Shipboard Scientific Party. Sample spacing varied, but generally included two samples per section of core, spaced $\sim 75 \mathrm{~cm}$ apart. Because the sample spacing was not adjusted to account for variations in sedimentation rates, biostratigraphic resolution is reduced in intervals with low-sedimentation rates relative to those intervals with high-sedimentation rates.

Standard smear slides were prepared from the interior portions of $2-\mathrm{cm}^{3}$ sample tubes. Optical adhesive (Norland \#61) was used as a mounting medium for all of the smear slides. Taxon identifications were performed using a Zeiss Universal microscope under magnifications of approximately $1250 \times$ and $500 \times$. The greater resolution provided by a JEOL JSM3000 scanning electron microscope (SEM) was used to verify the Emiliania huxleyi and large Gephyrocapsa $(>5.5 \mu \mathrm{m})$ datums from selected holes. A discussion of some species and biostratigraphic definitions used in this study is found in the Appendix in this chapter.

The nannofossil abundance data were compiled using a quantitative method that involved point counts of selected species. Unlike the Rio et al. (1990) study, which quantitatively documented a given species' abundance using several methods over the same interval (such as counting the number of specimens per fixed area of slide), this study only used a single method for each taxon studied. Although the total number of specimens counted differed between species, the method used throughout this study involved counting an index species vs. a fixed number of related forms. A discussion of the individual criteria used for each species can be found in the Appendix. The zonation scheme and datums identified in this study are shown in Figure 2.

Once determined through light microscopy, nannofossil abundance data from all samples were entered into a Microsoft Excel spreadsheet and eventually displayed as graphs using DeltaGraph software. The abundance patterns of the Leg 160 material are shown in Figures 3-6. The length and total values shown on the axes of all graphs of a given species were kept constant so that abundance pat- terns could be easily compared among holes. This graphical presentation style limits the reader's ability to accurately determine the precise abundance values where abundance fluctuates significantly (i.e., G. oceanica), but enhances the ability to recognize fluctuation trends for correlation among holes.

Many of the datums used in this study have been correlated with global magnetostratigraphy and oxygen isotope stages (Backman and Shackleton, 1983; Berggren et al., 1995; Cande and Kent, 1992, 1995; Shackleton et al., 1990; Sprovieri, 1993; Wei, 1993; VergnaudGrazzini et al., 1994; Zijderveld et al., 1991). The age assignments for all datums used in this study, including both zonal markers and additional datums, are found in Table 1.

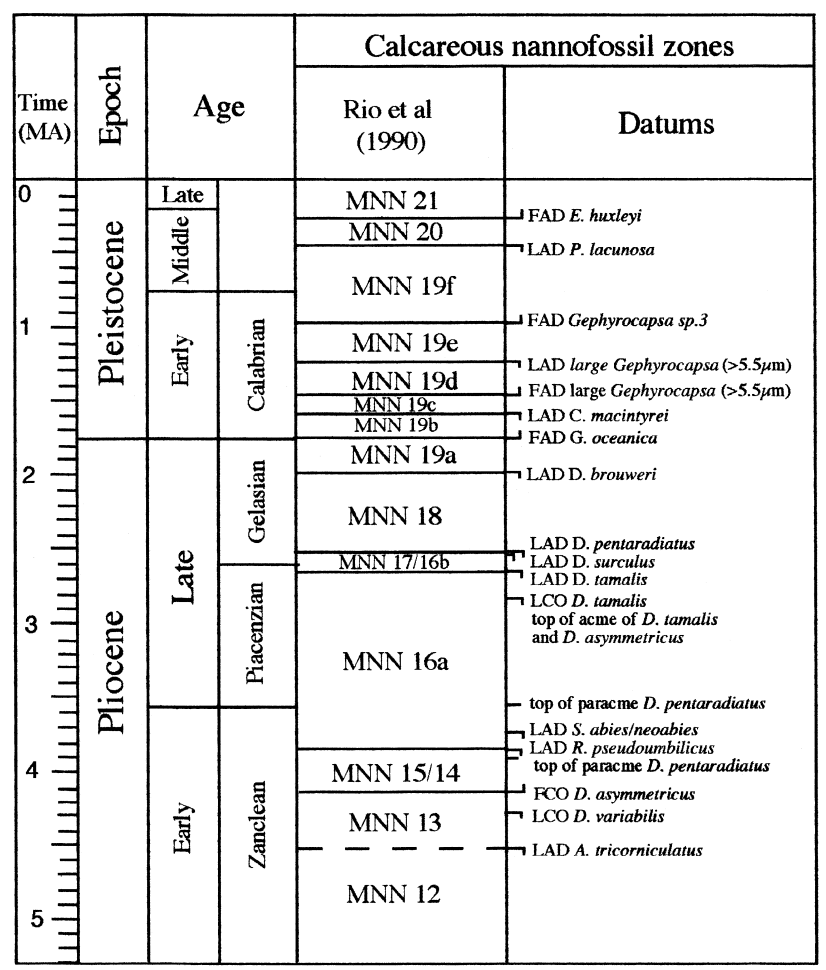

Figure 2. Pliocene and Pleistocene calcareous nannofossil zonation scheme that shows zonal boundary datums and additional datums correlated to the time scale of Berggren et al. (1995). FAD = first appearance datum, LAD = last appearance datum, FCO = first common occurrence, and LCO = last common occurrence.
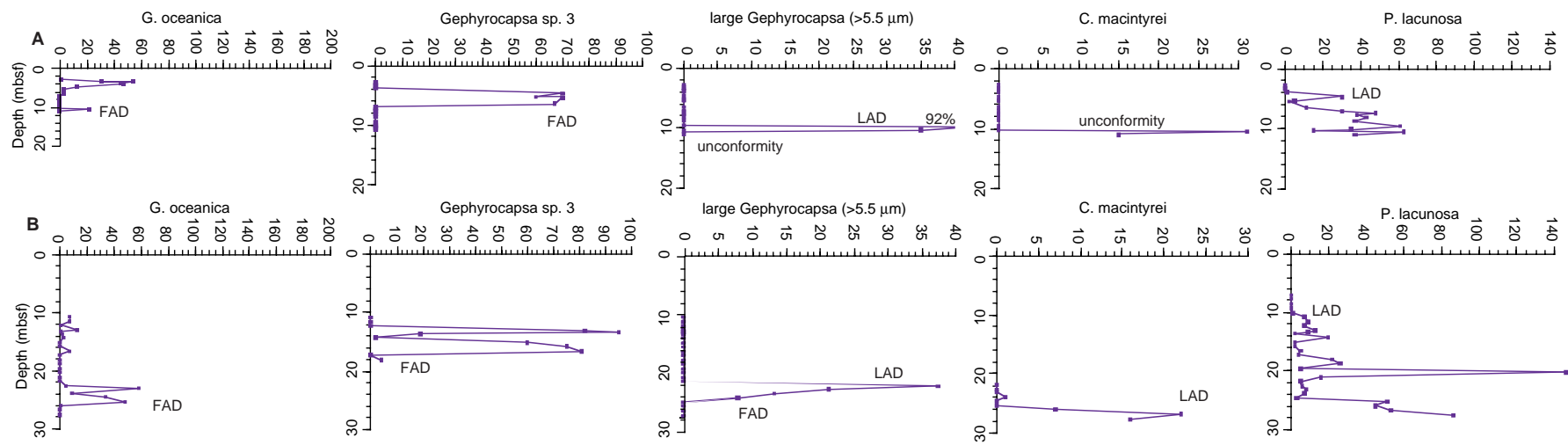

Figure 3. Graphs showing abundance patterns of biostratigraphically significant Pleistocene nannofossil species in samples collected from (A) Hole 965A and (B) Hole 966D relative to depth (mbsf). Abundance is shown as total specimens counted vs. a fixed number of related forms as described in the Appendix. 


\section{BIOSTRATIGRAPHIC INTERPRETATIONS Hole 965A}

Only one hole was drilled at Site 965 . The hole consisted of 27 cores that reached a total depth of $240.40 \mathrm{mbsf}$. Lithologies ranged from nannofossil ooze to clay in the upper four cores to packstones, grainstones, and wackestones containing only benthic foraminifers, mollusks, and algal laminations in Cores 160-965A-4H through 27X (Emeis, Robertson, Richter, et al., 1996). During postcruise nannofossil studies, 41 samples were analyzed from Core 160-965A-1H through $4 \mathrm{H}$. Graphs showing species abundance patterns are shown in Figures 3 and 4.

Emiliania huxleyi is present from Sample 160-965A-1H-1, 15-16 $\mathrm{cm}(0.15-0.16 \mathrm{mbsf})$ through $2 \mathrm{H}-1,20-22 \mathrm{~cm}$ (1.00-1.02 mbsf), which indicates that these samples are in Zone MNN 21. The E. huxleyi acme (Zone MNN 21b) was not identified in Hole 965A. The scanning electron microscope (SEM) was used to verify the placement of the first appearance datum (FAD) E. huxleyi.

In Sample 160-965A-2H-1, 109-110 cm (1.89-1.90 mbsf) through $2 \mathrm{H}-2,105-106 \mathrm{~cm}$ (3.35-3.36 mbsf) Zone MNN 20 is recognized by the absence of both E. huxleyi and Pseudoemiliania lacunosa. The accompanying assemblage includes Rhadosphaera claviger, Gephyrocapsa oceanica, small gephyrocapsids, Calcidiscus leptoporus, Syracosphaera pulchra, and Scapholithus fossilis. Although it was not studied quantitatively, Helicosphaera kamptneri was observed to fluctuate significantly throughout these samples. Reworked Cretaceous, Eocene, and Pliocene species, in addition to clay-sized and silt-sized calcite particles, also fluctuated throughout these samples.

Pseudoemiliania lacunosa becomes a consistent part of the assemblage beginning in Sample 160-965A-2H-3, 4-5 cm (3.84-3.85 mbsf). The presence of $P$. lacunosa means that this sample and those immediately below are within Zone MNN 19f. Although rare specimens of $P$. lacunosa were observed uphole, they were considered reworked. With the exception of an abundance peak in Sample 160965A-2H-3, 90-91 cm (4.70 mbsf), the uppermost $2.5 \mathrm{~m}$ of this zone is typified by low numbers of $P$. lacunosa (less than $2 \%$ P. lacunosa per 500 total coccolith count). Below $4.70 \mathrm{mbsf}, P$. lacunosa is a common part of the assemblage.

The last appearance datum (LAD) of Gephyrocapsa sp. 3, which is reported by Rio et al., 1990 as an alternate marker within Zone MNN 19f, was observed in Sample 160-965A-2H-3, 90-91 cm (4.70-4.71 mbsf). The quantitative method for determining the presence (or absence) of Gephyrocapsa sp. 3 follows the criteria of Rio et al. (1990) and is described in the Appendix. The base of Zone MNN $19 \mathrm{f}$, as indicated by the FAD of Gephyrocapsa sp. 3, is recognized in Sample 160-965A-2H-4, 116-117 cm (6.46-6.47 mbsf). An increase in abundance in $P$. lacunosa was also noticed at $6.46 \mathrm{mbsf}$. The recognition of the FAD and LAD of Gephyrocapsa sp. 3 in successive samples (1.08 m apart) suggests that either an unconformity exists between these samples or the samples are within an interval characterized by very low sedimentation rates (approximately $4.3 \mathrm{~m} / \mathrm{m} . \mathrm{y}$.).

The next significant change in the nannofossil assemblage occurs where large Gephyrocapsa $(>5.5 \mu \mathrm{m})$ is recognized in Sample 160965A-2H-7, 28-29 cm (10.08-10.09 mbsf). Large Gephyrocapsa is observed in only two samples. The FAD was identified in Sample 160-965A-2H-CC (10.28-10.30 mbsf), whereas the LAD was identified in Sample 160-965A-2H-7, 28-29 cm (10.08-10.09 mbsf). Together, these two samples comprise Zone MNN 19d.

In Sample 160-965A-3H-1, 21-22 cm (10.51-10.52 mbsf), Calcidiscus macintyrei becomes a common part of the nannofossil assemblage. Typically, the LAD of $C$. macintyrei signifies the top of Zone 19b; however, the absence of G. oceanica in this sample indicates that the sample is actually within Zone 19a. Collectively, the FADs of large Gephyrocapsa and G. oceanica (Sample 160-965A2H-CC) juxtaposed to the LAD of C. macintyrei (160-965A-3H-1,
21-22 cm) in successive samples indicates that an unconformity exists between $10.30 \mathrm{mbsf}$ and $10.52 \mathrm{mbsf}$. Within the interval represented by the unconformity, sediments comprising Zones MNN 19c and MNN 19b are entirely missing, and portions of Zone MNN 19a and MNN 19d may also be missing. The missing sediments represent a length of time that ranges from a maximum of $1.10 \mathrm{Ma}$ to $2.02 \mathrm{Ma}$, to a minimum span from $1.47 \mathrm{Ma}$ to $1.72 \mathrm{Ma}$ (Fig. 2 and Table 1). According to this interpretation, sediments spanning the Pleistocene/ Pliocene boundary are not present in Hole 965A.

In Sample 160-965A-3H-1, 135-136 cm (11.65-11.66), a nannofossil assemblage typified by the presence of Discoaster brouweri and Discoaster triradiatus is observed. Owing to the absence of other discoasters, this sample is assigned to Pliocene Zone MNN 18. The accompanying assemblage includes $C$. leptoporus, C. macintyrei, small reticulofenestrids, and $H$. kamptneri.

Discoaster pentaradiatus is observed in Sample 160-965A-3H-3, 99-100 cm (14.29-14.30 mbsf), which marks the uppermost limit of Zone 17-16b. At 15.72 mbsf, below the LAD of D. pentaradiatus, the LAD of Discoaster surculus is observed. Discoaster surculus is used in extra-mediterranean zonation schemes (Okada and Bukry, 1980; Martini,1971) as a zonal marker; however, in the Mediterranean, the LADs of $D$. pentaradiatus and $D$. surculus are virtually indistinguishable (Rio et al, 1990; Müller, 1978; Driever, 1981; and Ellis and Lohman, 1979). Following the zonation scheme of Rio et al. (1990), the two species are placed at the top of Zone MNN 17-16b.

In Sample 160-965A-3H-5, 96-97 cm (17.26-17.27), Discoaster tamalis is observed in abundances greater than $2 \%$ of the total discoaster population. Following the criteria of Rio et al. (1990), the downhole increase in D. tamalis greater than $2 \%$ of the discoaster population indicates that this sample is within Zone MNN 16a. All occurrences of D. tamalis identified uphole were less than $2 \%$ and thus, are considered above the datum. Because D. tamalis fluctuates to rare or absent near its LAD, Rio et al. (1990) and Sprovieri (1993) cite the importance of using a close sample spacing to accurately identify the zonal boundary. The average sample spacing used in this study was $74 \mathrm{~cm}$, which is considerably greater than the average spacings used by Rio et al. (1990) $(40 \mathrm{~cm}$ to $10 \mathrm{~cm})$ and Sprovieri (1993) $(25 \mathrm{~cm})$ in their respective studies. For this reason, the LAD of $D$. tamalis datum in this study may have been placed lower in the geologic record compared to the Rio et al. (1990) and Sprovieri (1993) studies. Discoaster tamalis remains a continual part of the nannofossil assemblage downhole and increases in abundance near $30 \%$ of the total discoaster assemblage in Sample 160-965A-4H-1, $42-43 \mathrm{~cm}(20.22-20.23 \mathrm{mbsf})$. The increase in abundance of $D$. $t a-$ malis is coincident with increases in the abundance of Discoaster asymmetricus and a single spike in the abundance pattern of $D$. pentaradiatus. In Sample 160-965A-4H-2, 29-30 cm (21.59-21.60 mbsf), immediately below the increases in D. tamalis and D. asymmetricus, Sphenolithus abies/neoabies becomes a consistent part of the assemblage. In addition to the LAD of Sphenolithus abies/neoabies, assemblage changes that include the absence of both $D$. pentaradiatus and D. tamalis, the dramatic decrease of D. asymmetricus, and a marked increase in the abundance of $D$. surculus are observed in Sample 160-965A-4H-2, 29-30 cm (21.59-21.60 mbsf). The absence of $D$. pentaradiatus in the lowermost portion of Zone MNN $16 \mathrm{a}$ is a consistent event observed in the Central Mediterranean and first described as a paracme event by Driever (1988). The assemblage that includes D. tamalis in the absence of $R$. pseudoumbilicus and D. pentaradiatus (paracme) is observed in only one sample in Hole $965 \mathrm{~A}$, which suggests that either the sedimentation rates are low or erosion has removed most of the $D$. pentaradiatus paracme interval in Hole 965A.

Reticulofenestra pseudoumbilicus (Zone MNN 14-15) is present beginning in Sample 160-965A-4H-2, 97-98 cm (22.27-22.28 mbsf). In the following sample (23.15-23.16 mbsf), which is the deepest sample studied in Hole 965A, another significant change in 
A

D. brouweri

D. triradiatus

D. pentaradiatus

D. surculus
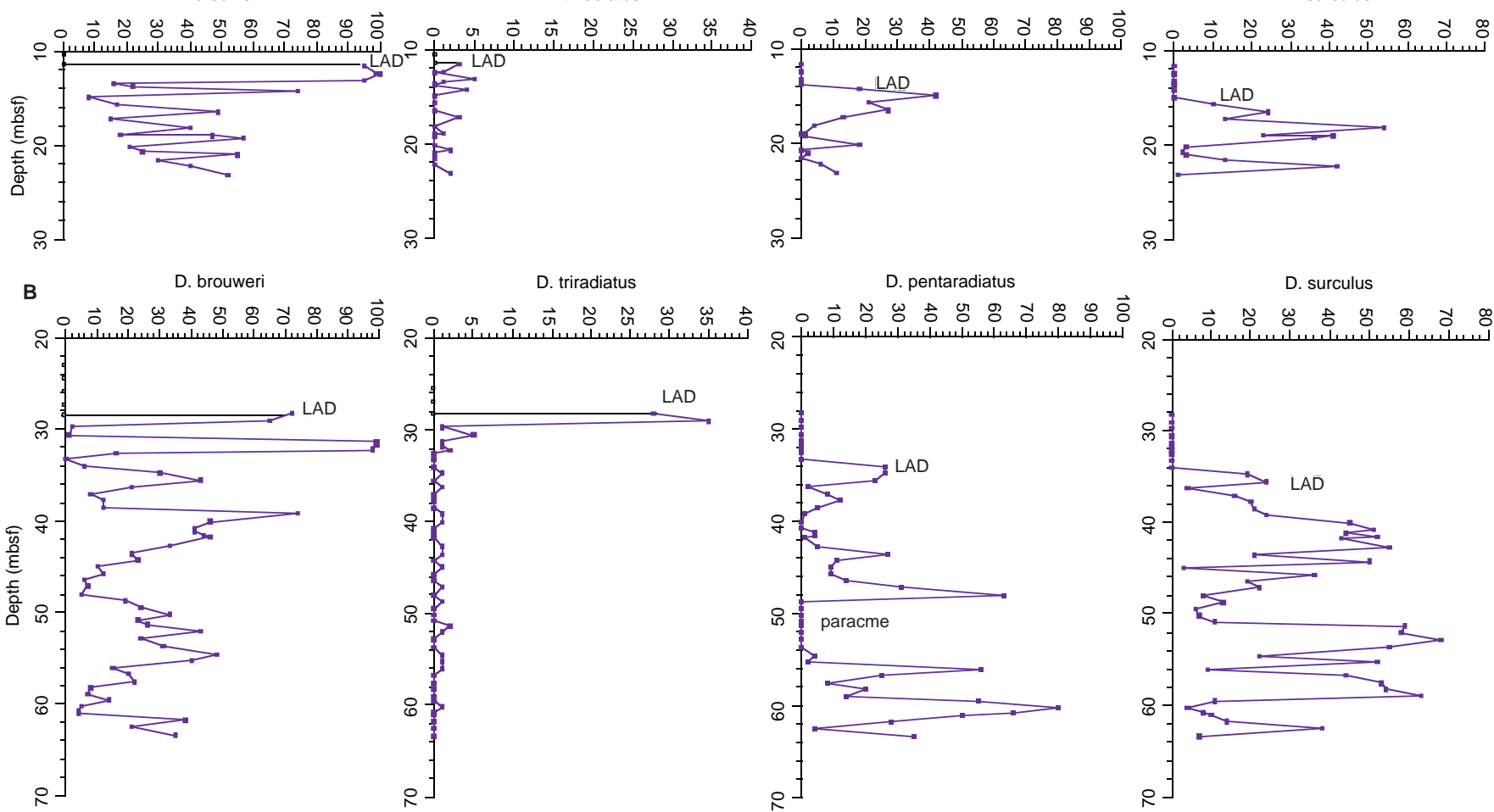

C

D. brouweri

D. triradiatus

D. pentaradiatus

D. surculus
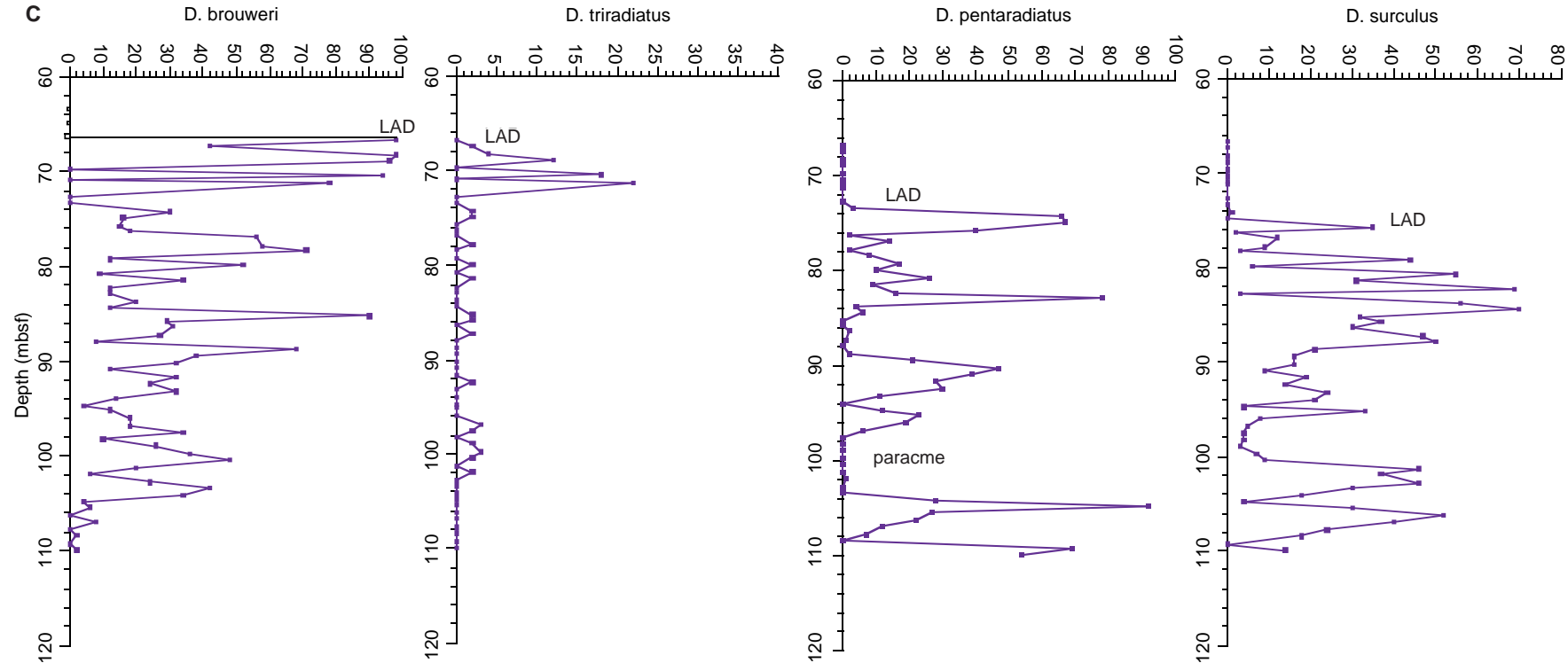

Figure 4. Graphs showing abundance patterns of selected Discoaster species in samples collected from (A) Hole 965A, (B) Hole 966D, and (C) Hole 967A relative to depth (mbsf). Abundance for each species is shown as the percent of the total discoaster assemblage counted.

nannofossil assemblage is observed: P. lacunosa and D. asymmetricus are absent, Discoaster variabilis becomes a significant part of the discoaster assemblage (Fig. 4A), and Ceratolithus delicatus is observed for the first time downhole. Collectively, the floral changes suggest the presence of an unconformity in which some of Zones MNN 15/14 and MNN 13 may be missing. A coincident minor lithologic change typified by an abundance of calcite fragments is also observed between 22.23 and 23-15 mbsf. Further discussion of all suspected unconformities and comparisons with other Leg 160 holes are located in the "Stratigraphic Discussion" section, which follows.

\section{Hole 966D}

Because Site 966 is at the crest of the seamount, it would be expected to be least altered by slumping and faulting associated with collapse of the seamount during subduction. Site 966 potentially offered the most complete geologic section of Pleistocene and Pliocene deposits of any of the sites along the Eratosthenes Seamount transect. However, some missing intervals attributed to unconformities were identified in Hole 966D during postcruise studies. The other holes at Site $966 \mathrm{D}$ were not studied during postcruise research. Calcareous 

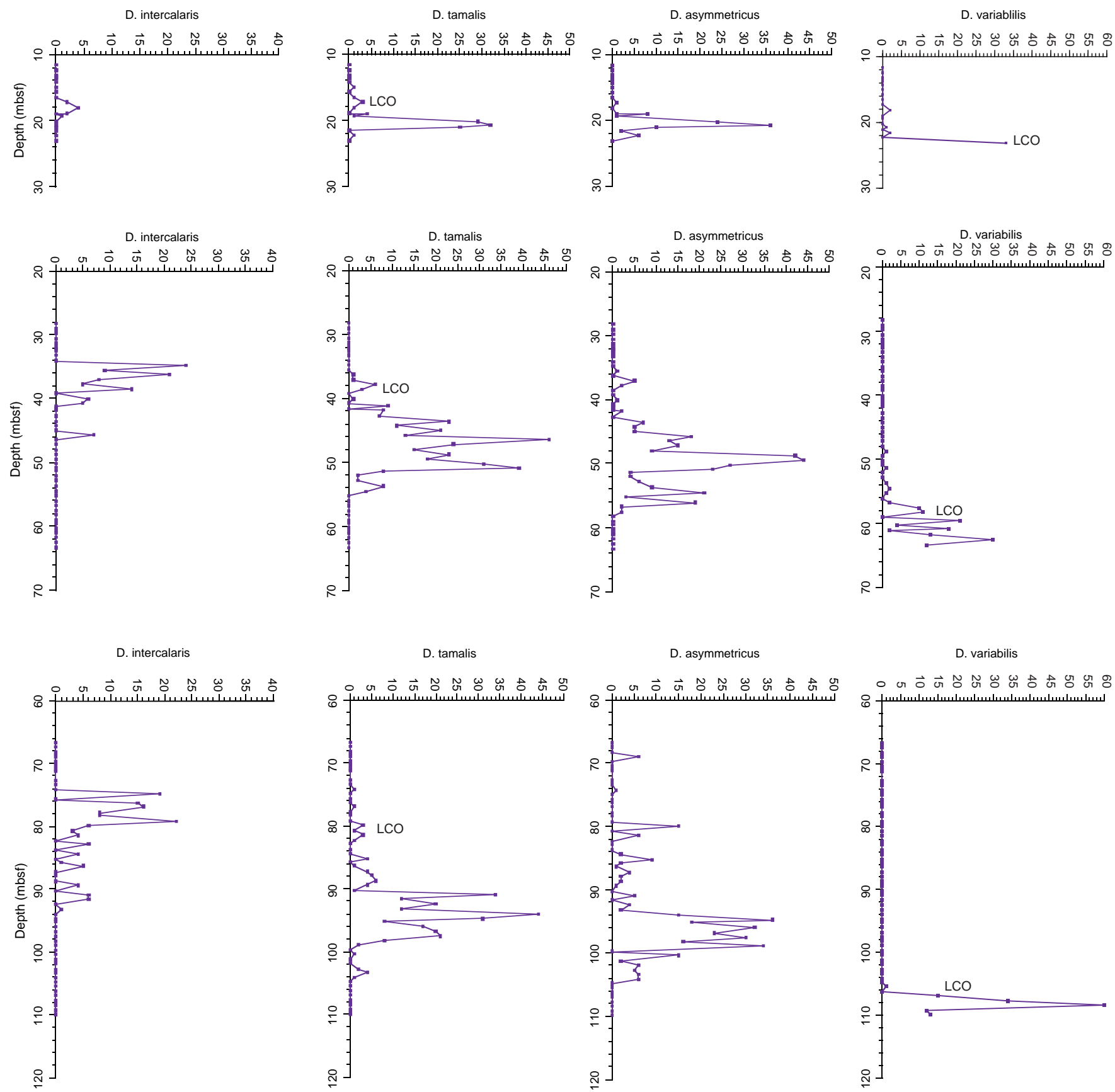

Figure 4 (continued).

nannofossil abundance patterns for Hole 966D are shown in Figures 3B and 4B.

Pleistocene hemipelagic oozes comprise the uppermost cores from Hole 966D. The interval from Sample 160-966D-1H-1, 60-61 (0.60-0.61 mbsf) to Sample 160-966D-2H-1, 125-126 cm (4.75$4.76 \mathrm{mbsf}$ ) contains a rare to common, well-preserved nannofossil assemblage typical of the uppermost Pleistocene Zone MNN 21, as indicated by the presence of E. huxleyi. Core 160-966D-1H contains some reworked Pliocene, Eocene, and Cretaceous taxa, in addition to abundant silt- and clay-sized calcite fragments of unknown origin. Gephyrocapsa oceanica, small and medium gephyrocapsids $(<4$ $\mu \mathrm{m})$, R. claviger, H. kamptneri, S. fossilis, C. leptoporus, U. mirabilis, and $S$. pulchra also occur in this interval interpreted as Zone
MNN 21. The acme zone of E. huxleyi was not recognized in Hole 966D.

In Sample 160-966D-2H-2, 51-52 cm (5.51-5.52 mbsf) E. huxleyi can no longer be identified in the assemblage. Because of its small size and paucity near its first occurrence, E. huxleyi is difficult to identify in the lowermost portion of its range. To confirm the placement of the FAD of E. huxleyi, five samples (160-966D-1H-1, 125-126 through 160-966D-2H-3, 60-61 cm) that spanned the FAD of E. huxleyi were also viewed in the SEM. In the SEM study, placoliths were counted in excess of 500 specimens in the search for $E$. huxleyi fragments. Because no fragments of E. huxleyi were observed below $5.52 \mathrm{mbsf}$ in the SEM study, the placement of the E. huxleyi datum as determined by light microscopy appears accurate. Samples 

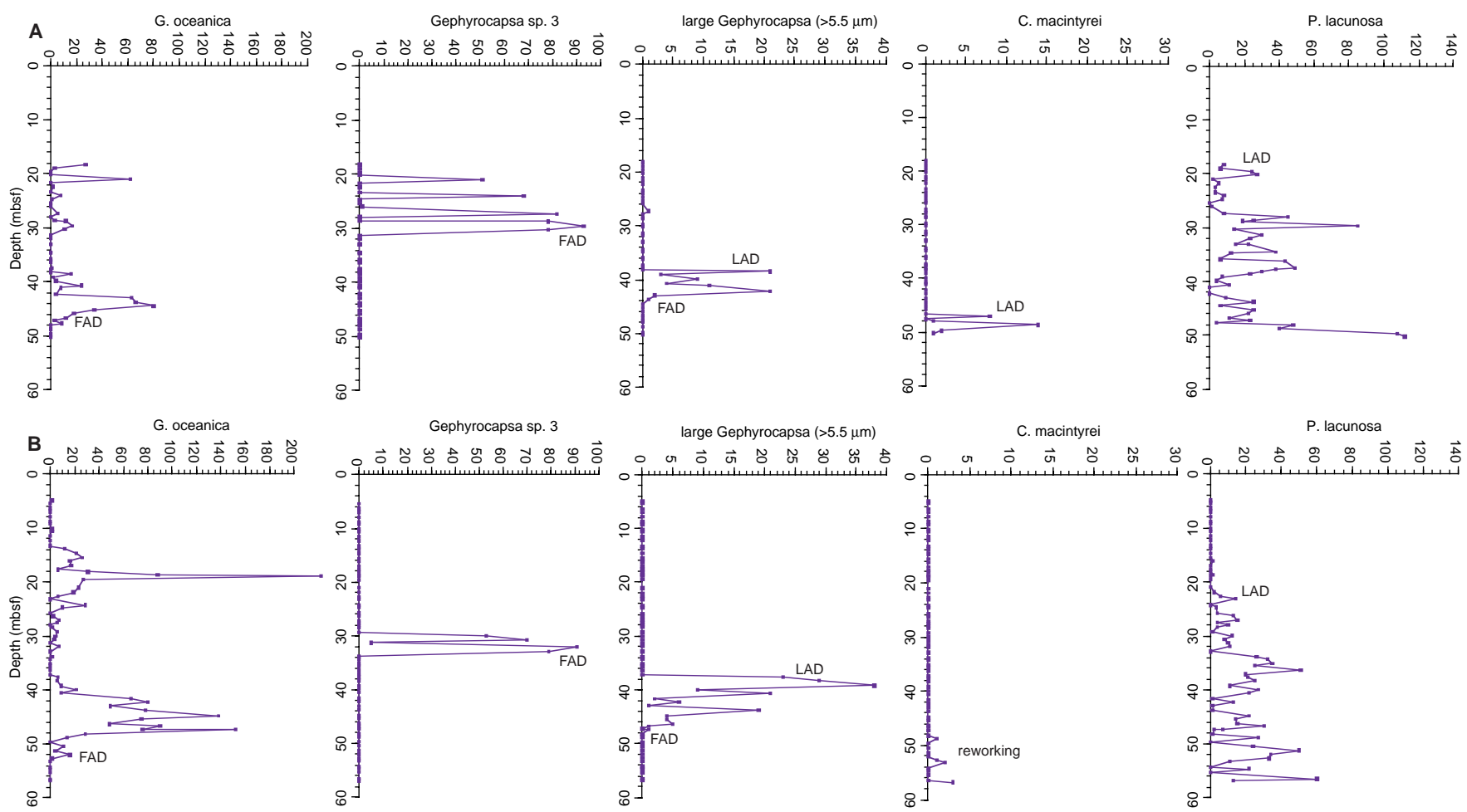

Figure 5. Graphs showing abundance patterns of biostratigraphically significant Pleistocene nannofossil species in samples collected from (A) Hole 967C and (B) Hole 968A relative to depth (mbsf). Abundance is shown as total specimens counted vs. a fixed number of related forms as described in the Appendix.

from $160-966 \mathrm{D}-2 \mathrm{H}-2,51-52 \mathrm{~cm}(5.51-5.52 \mathrm{mbsf})$ through $2 \mathrm{H}-5$, $125-126 \mathrm{~cm}(10.75-10.76 \mathrm{mbsf})$ lack both E. huxleyi and P. lacun$o s a$; therefore, these samples are assigned to the upper Pleistocene Zone MNN 20. A typical assemblage within this zone consists of $G$. oceanica, small and medium gephyrocapsids $(<4 \mu \mathrm{m}), R$. claviger, $H$. kamptneri, S. fossilis, C. leptoporus, U. mirabilis, and S. pulchra.

The presence of $P$. lacunosa beginning in Sample $160-966 \mathrm{D}-2 \mathrm{H}-$ $5,125-126 \mathrm{~cm}(10.75-10.76 \mathrm{mbsf})$ indicates that this sample is within middle Pleistocene Zone MNN 19f. The accompanying assemblage is similar to that found uphole and continues through sample $160-966 \mathrm{D}-2 \mathrm{H}-6,125-126 \mathrm{~cm}$ (12.25-12.26). In the interval from 160-966D-2H-7, 60-61 cm (13.10-13.11 mbsf) through 3H-4, 60$61 \mathrm{~cm}$ (18.10-18.11 mbsf) Gephyrocapsa sp. 3 becomes a noticeable part of the assemblage. This interval is placed in the lowermost portion of Zone $19 \mathrm{f}$.

The interval from $160-966 \mathrm{D}-3 \mathrm{H}-4,125-126 \mathrm{~cm}(18.75-18.76$ mbsf) through $3 \mathrm{H}-6,125-126 \mathrm{~cm}(21.75-21.76 \mathrm{mbsf})$ is interpreted as Zone MNN 19e. Zone MNN 19e is defined by the absence of both Gephyrocapsa sp. 3 and the next lower biostratigraphic marker, large Gephyrocapsa $(>5.5 \mu \mathrm{m})$. This interval also lacks G. oceanica. The remaining assemblage is similar to that found in the preceding zone.

The LAD of large Gephyrocapsa $(>5.5 \mu \mathrm{m})$ occurs in Sample 160-966D-3H-7, 60-61 (22.60-22.61 mbsf). Large Gephyrocapsa remains a part of the assemblage through Sample 160-966D-4H-1, $60-61 \mathrm{~cm}$ (24.60-24.61 mbsf). Because only a minor size variation was detected in the light microscope below the FAD of large Gephyrocaps,$(>5.5 \mu \mathrm{m})$, five samples spanning the FAD were studied under the SEM for confirmation. In the SEM study, 100 gephyrocapsid specimens larger than $4.0 \mu \mathrm{m}$ were counted to document the presence of gephyrocapsid forms larger than $5.5 \mu \mathrm{m}$. Because no specimens larger than $5.5 \mu \mathrm{m}$ were observed below the boundary, the SEM study confirmed the placement of the boundary as previously defined by use of the light microscope. All samples that included large Gephyrocapsa $(>5.5 \mu \mathrm{m})$ were assigned to Zone MNN 19d.

In Sample 160-966D-4H-2, 129-130 cm (25.29-25.30 mbsf), the absence of large Gephyrocapsa $(>5.5 \mu \mathrm{m})$ and the next downhole marker, C. macintyrei indicates Zone MNN 19c. The next significant change in the microfloral assemblage occurs in Sample 160-966D$4 \mathrm{H}-3,47-48 \mathrm{~cm},(25.97-25.98 \mathrm{mbsf})$ where the LAD of $C$. macintyrei and the FAD of G. oceanica are observed. This sample is assigned to Zone MNN 19b. The co-occurrence of C. macintyrei and G. oceanica in the same sample combined with Zone MNN 19c being represented by only one sample indicates that most of Zone $19 \mathrm{~b}$ is missing $(0.16$ to $0.60 \mathrm{Ma})$. It is likely that some of the overlying or underlying zones are also missing. Because the single sample represents the lowermost Pleistocene Zone 19b, it is uncertain whether the Pleistocene/Pliocene boundary is present in Hole 966D or if the boundary is represented by an unconformity.

Uppermost Pliocene Zone MNN 19a, defined by the absence of both G. oceanica and D. brouweri, is recorded from Samples 160$966 \mathrm{D}-4 \mathrm{H}-3,125-126 \mathrm{~cm}$ (26.75 mbsf) through $4 \mathrm{H}-4,62-63 \mathrm{~cm}$ (27.62 mbsf).

In Sample 160-966D-4H-4, 122-123 cm (28.22 mbsf) the LADs of $D$. brouweri and $D$. triradiatus were identified. Although very rare occurrences of other discoasters were observed in some samples, $D$. brouweri and $D$. triradiatus were interpreted to be the only in situ discoasters in the interval from 160-966D-4H-4, 122-123 (28.22-28.23 mbsf) through 160-966D-5H-1, 125-126 cm (33.25-33.26 mbsf), thus indicating that these samples are within Zone MNN 18.

Discoaster pentaradiatus becomes a consistent part of the assemblage beginning in Sample 160-966D-5H-2, 59-60 cm (34.09-34.10 mbsf). The presence of $D$. pentaradiatus in the absence of $D$. tamalis indicates that the Samples from 160-966D-5H-2, 59-60 cm (34.09$34.10 \mathrm{mbsf}$ ) through $160-966 \mathrm{D}-5 \mathrm{H}-4,59-60 \mathrm{~cm}$ (37.09-37.10 mbsf) 
are in Zone MNN 17-16b. In Hole 966D, the LAD of D. surculus occurs in Sample 160-966D-5H-2, 125-126 cm (34.75-34.75 mbsf). Rare occurrences of D.tamalis also occur in the lower portion of Zone MNN 17-16b; however, the number of D. tamalis specimens recorded in these samples are less than $2 \%$ of the total discoaster assemblage and are therefore considered to be biostratigraphically insignificant.

As shown in Figure 4B, the point at which D. tamalis reaches $2 \%$ of the total discoaster assemblage (top of Zone MNN 16a) occurs in Sample 160-966D-5H-4, 125-126 cm (37.75-37.76 mbsf). Zone MNN 16a continues through Sample 160-966D-7H-1, 106-107 cm (52.06-52.07 mbsf). Although they are not considered as primary biostratigraphic markers, abundance increases in D. tamalis and $D$. pentaradiatus also occur within Zone MNN 16a. Beginning in Sample 160-966D-6H-2, 60-61 cm (43.60-43.61 mbsf), D. tamalis increases significantly in abundance. This shift is evident in the abundance graph shown in Figure 4B and is likewise evident in similar graphs of species abundance from ODP Site 653 drilled in the Western Mediterranean (Rio et al., 1990).

Like $D$. tamalis, the abundance of $D$. pentaradiatus fluctuates in the samples interpreted to be in Zone MNN 16a. In the upper portion of this zone, $D$. pentaradiatus is a consistent part of the assemblage and constitutes the most significant component of the discoaster assemblage; however, beginning in Sample 160-966D-6H-5, 125-126 $\mathrm{cm}$ (48.74-48.75 mbsf) and extending into the next lower zone (at $54.61 \mathrm{mbsf}$ ), D. pentaradiatus is absent. The absence of $D$. pentaradiatus represents the paracme. Stratigraphically, the interval in Hole $966 \mathrm{D}$, which is interpreted as the top of the paracme of $D$. pentaradiatus, appears to coincide with paracme intervals documented in the Western Mediterranean (Driever, 1988; Rio et al., 1990; Channell et al., 1992; Sprovieri, 1993; Castradori, 1993; and Di Stefano, Chap. 8, this volume).

The lowermost sample interpreted as Zone MNN 16a (Sample 160-966D-7H-1, 106-107 cm) contains the LAD of Sphenolithus abies/neoabies. Sphenolithus abies/neoabies is used as an alternate marker near the base of Zone MNN 16a in the zonation scheme of Rio et al. (1990).

In Sample 160-966D-7H-2, 33-34 cm (52.83-52.84 mbsf), the presence of $R$. pseudoumbilicus is recognized. The LAD of this species marks the top of Zone MNN 15-14. In the upper portion of Zone MNN 15-14, D. pentaradiatus is absent from the assemblage, indicating that the samples assigned to Zone MNN 15-14 above 53.70 remain in the paracme interval of $D$. pentaradiatus. In Sample 160966D-7H-3, 61-62 cm (54.61-54.62 mbsf), D. pentaradiatus reenters the assemblage. The shallowest sample before the onset of the paracme zone for $D$. pentaradiatus is coincident with the FAD of $D$. tamalis. The concomitance of the onset of the D. pentaradiatus paracme and FAD of $D$. tamalis is not documented in other holes from Leg 160 and suggests a minor unconformity. The unconformity probably represents less than 100,000 years of missing sediments between Samples 160-966D-5H-3, 61-62 cm (54.61-54.62 mbsf), and 160-966D-7H-2, 120-121 cm (53.70-53.71 mbsf). Zone MNN 1415 continues to Sample $160-966 \mathrm{D}-7 \mathrm{H}-4,124-125 \mathrm{~cm}(56.74-56.75$ mbsf) where the LAD of Amaurolithus delicatus and the FAD of Discoaster asymmetricus are observed. The FAD of D. asymmetricus marks the base of Zone MNN 15-14. In Hole 966D, the last common occurrence (LCO) of $D$. variabilis is coeval with the FAD of $D$. asymmetricus.

The interval between the FAD of D. asymmetricus to the LAD of Amaurolithus tricorniculatus is interpreted as Zone MNN 13 and spans from Sample 160-966D-7H-5, 59-60 cm (57.59 mbsf) through $7 \mathrm{H}-\mathrm{CC} 14-15 \mathrm{~cm}$ (60.81 mbsf). Because the abundance pattern of Helicosphaera sellii was not established during this study, the LAD of A. tricorniculatus is used as an alternate marker to approximate the base of Zone MNN 13. The accompanying assemblage is dominated by $D$. surculus, D. pentaradiatus, and $D$. variabilis.
The interval from Sample 160-966D-8H-1, 59-60 cm (61.09 mbsf) through $8 \mathrm{H}-4,65-66 \mathrm{~cm}$ (65.65 mbsf) contained rare occurrences of Amaurolithus tricorniculatus and is assigned to Zone MNN 12. No samples were analyzed in this study below Sample 8H-4, 65$66 \mathrm{~cm}$ (65.65 mbsf). Samples from Hole 966D collected below Section $966 \mathrm{D}-8 \mathrm{H}$ that are assigned to the basal Zanclean stage (Zone MNN 12) are discussed by Castradori et al., Chap. 9, this volume.

\section{Hole 967C}

Site 967 was located above the active subduction zone at the base of the northern flank of the seamount. Sediments and rocks recovered from Site 967 were more diverse in age than those from the other sites drilled during Leg 160 (Emeis, Robertson, Richter, et al., 1996). Hole 967C was one of three holes drilled at Site 967. Hole 967C cored only Holocene through upper Pliocene age sediments. Abundance patterns for selected species studied from Hole 967C are shown in Figures 5A and $6 \mathrm{~A}$.

The uppermost sediments studied for nannofossils contained $E$. huxleyi, which is indicative of the upper Pleistocene Zone MNN 21. The uppermost Pleistocene Zone MNN 21b was not distinguished in the cores from Site 967C. Abundance of E. huxleyi shifted dramatically throughout the uppermost samples with abundance estimates fluctuating from $5 \%$ up to $70 \%$ of the total coccolith assemblage in the uppermost cores. A significant decline in the abundance occurs at Sample 160-967C-1H-2, 121-122 cm (2.71-2.72 mbsf), where E. huxleyi drops to below an estimated $1 \%$ of the total coccolith assemblage and is missing entirely from several additional samples downhole.

Each sample that exhibits a paucity of E. huxleyi in Hole 967C also contains reworked Cretaceous, Eocene, Miocene, and Pliocene specimens. Clay- and silt-sized calcite particles are also present. Preservation of the nannofossils in the intervals that contain reworked specimens is generally poor to fair with most specimens broken. The base of the E. huxleyi zone was observed in Sample 160967C-1H-5, 50-51 cm (6.50-6.51 mbsf). The placement of this datum was confirmed though SEM study of the interval from 160$967 \mathrm{C}-1 \mathrm{H}-2,46-47 \mathrm{~cm}$, through $1 \mathrm{H}-5,120-121 \mathrm{~cm}$.

The interval from Sample 160-967C-1H-5, 120-121 cm (7.20$7.21 \mathrm{mbsf})$ through Sample 160-967C-2H-6, 46-47 cm (17.46-17.47 mbsf) is placed into Zone MNN 20, because of a lack of both $E$. huxleyi and the next oldest biostratigraphic datum, P. lacunosa. The accompanying assemblage is similar to that found within this zone in other Leg 160 holes.

In Sample 160-967C-2H-6, 121-122 cm (18.21-18.22 mbsf), $P$. lacunosa becomes a consistent part of the nannofossil assemblage. Based on the presence of $P$. lacunosa, this sample is assigned to Zone MNN 19. This species fluctuates significantly downhole, but in the initial two samples below its LAD, P. lacunosa occurs in concentrations less than $2 \%$ of the total nannofossil assemblage.

In Sample 160-967C-3H-2, 55-57 cm (21.05-21.06 mbsf), Gephyrocapsa sp. 3 is first observed downhole. The abundance of $G e$ phyrocapsa sp. 3 fluctuates considerably in the next $10 \mathrm{~m}$ downhole. In the six samples immediately below the recognized LAD of Gephyrocapsa sp. 3, only one sample contains Gephyrocapsa sp. 3. However, as shown in Figure 5A, the species abundance patterns shows that Gephyrocapsa sp. 3 dominates the assemblage of gephyrocapsids larger than $4 \mu \mathrm{m}$. Also noteworthy is the length of the interval that contains Gephyrocapsa sp. 3 and the onset of this datum relative to the LAD of P. lacunosa. The LAD of Gephyrocapsa sp. 3 is recognized by Rio et al. (1990) to occur in the middle of MNN 19f, but in Hole 967C it occurs at the top of the zone and extends for a greater interval than the portion of Zone MNN $19 \mathrm{f}$ that overlies it. This relationship suggests that either the placement of the LAD of $P$. lacunosa occurs along an unconformity rather than at its true extinction, or that the interval containing Gephyrocapsa sp. 3 is an expanded section re- 

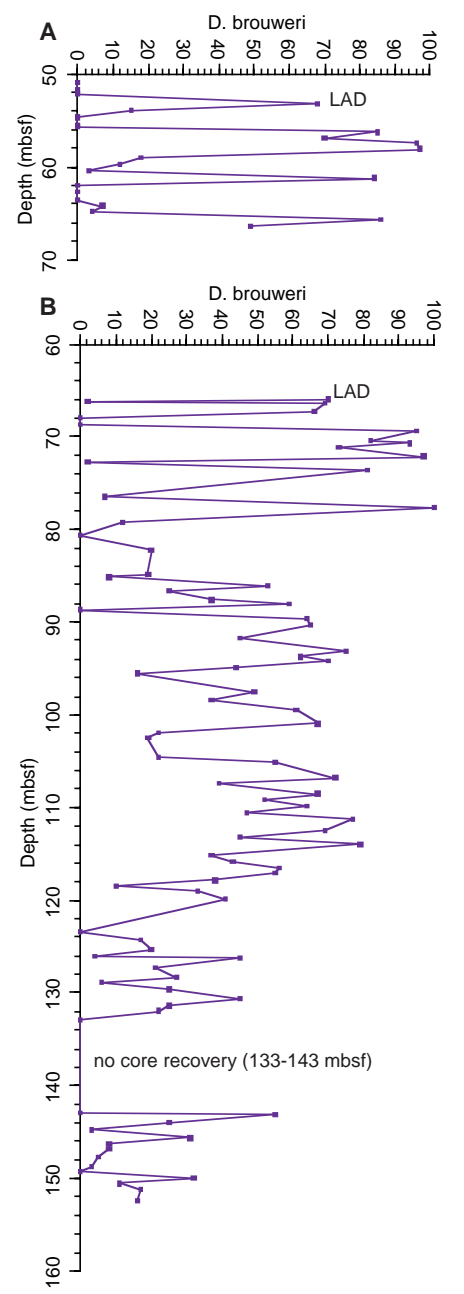
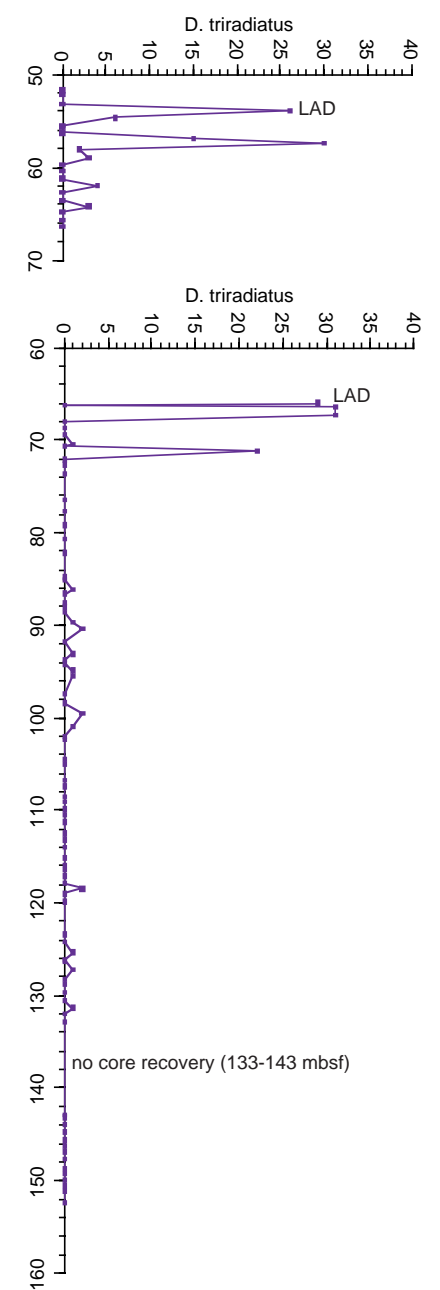
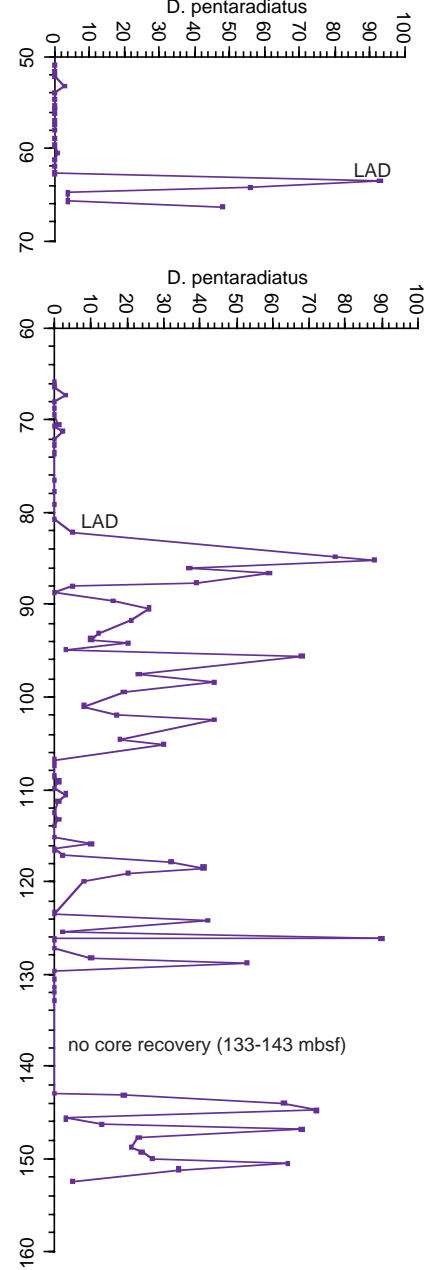
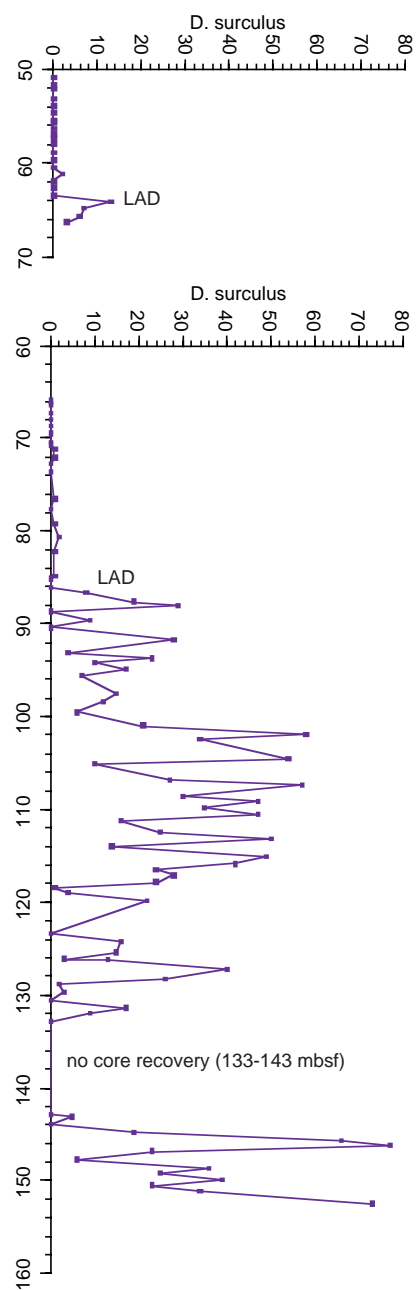

Figure 6. Graphs showing abundance patterns of selected Discoaster species in samples collected from (A) Hole 967C and (B) Hole 968A relative to depth (mbsf). Abundance for each species is shown as the percent of the total discoaster assemblage counted.

sulting from increased sedimentation rates. The base of Zone MNN 19f, as marked by the FAD of Gephyrocapsa sp. 3, is identified in Sample 160-967C-4H-2, 22-23 cm (30.22-30.23 mbsf).

The interval spanning from Sample 160-967C-4H-2, 22-23 cm (30.22-30.23 mbsf) through Sample 160-967C-4H-7, 64-65 cm (38.14-38.15 mbsf) is dominated by small Gephyrocapsa and contains neither Gephyrocapsa sp. 3 nor large Gephyrocapsa $(>5.5 \mu \mathrm{m})$. With the exception of one sample, this interval was also devoid of $G$. oceanica. Based on this assemblage, the sample from 30.22 to 38.15 mbsf is assigned to Zone MNN 19e.

In Sample 160-967C-5H-1, 48-49 cm (38.48-38.49 mbsf), an assemblage change that includes the LAD of large Gephyrocapsa $(>5.5$ $\mu \mathrm{m})$ and the reappearance of $G$. oceanica after an absence in the previous zone. Specimens of large Gephyrocapsa $(>5.5 \mu \mathrm{m})$ continue through Sample 160-967C-5H-4, 121-122 cm (43.71-43.72 mbsf). Although the abundance of large Gephyrocapsa $(>5.5 \mu \mathrm{m})$ is less than $10 \%$ of the total gephyrocapsid population larger than $4 \mu \mathrm{m}$, it is an important species within this interval because its LAD and FAD denote the top and bottom of Zone MNN 19d.

The interval between the FAD of large Gephyrocapsa $(>5.5 \mu \mathrm{m})$ and the LAD of $C$. macintyrei in Sample 160-967C-5H-7, 18-19 cm $(47.18-47.19 \mathrm{mbsf})$ is identified as Zone MNN 19c. Below Zone MNN 19c, the interval containing both $C$. macintyrei and G. oceani$c a$ is assigned as Zone MNN 19b. Compared to samples collected immediately uphole, $G$. oceanica diminishes in number within Zone MNN 19b. The base of Zone MNN 19b as marked by the FAD of $G$. oceanica is observed in Sample 160-967C-5H-7, 65-66 cm (47.65$47.66 \mathrm{mbsf}$ ) and is used in this study to approximate the location of the Pleistocene/Pliocene boundary.

In Sample 160-967C-5H-7, 65-66 cm (47.65-47.66 mbsf) through Sample 160-967C-6H-4, 19-20 cm (52.19-52.20 mbsf) uppermost Pliocene Zone MNN 19a was identified by the absence of both $G$. oceanica and any discoasters that were interpreted to be in situ.

Beginning in Sample 160-967C-6H-4, 120-121 cm (53.20-53.21 mbsf), D. brouweri and $D$. triradiatus are first observed downhole, which indicates that this sample is within Zone MNN 18. With the exception in some samples of rare occurrences of other discoasters interpreted as reworked, $D$. brouweri and $D$. triradiatus are the only discoaster species common from Samples 160-967C-6H-4, 120-121 $\mathrm{cm}$ (53.20-53.21 mbsf) through 7H-4, 120-121 cm (62.70-62.71 mbsf). Both $D$. brouweri and $D$. triradiatus populations fluctuate significantly from Sections 160-967C-7H-2 through 7H-4, with most samples containing either few or no discoasters. At Sample 160967C-7H-5, 53-54 cm (63.53-63.54 mbsf) the discoaster population again increases, but the discoaster assemblage is comprised almost entirely of $D$. pentaradiatus.

The LAD of D. pentaradiatus marks the top of Zone MNN 17$16 \mathrm{~b}$ in Sample 160-967C-7H-5, 53-54 cm (63.53 mbsf). As was noted in Hole 965A and 966D, the LAD of D. surculus is recognized in the sample immediately downhole from the LAD of $D$. pentaradiatus. The LAD of D. intercalaris was also observed in Sample 160- 

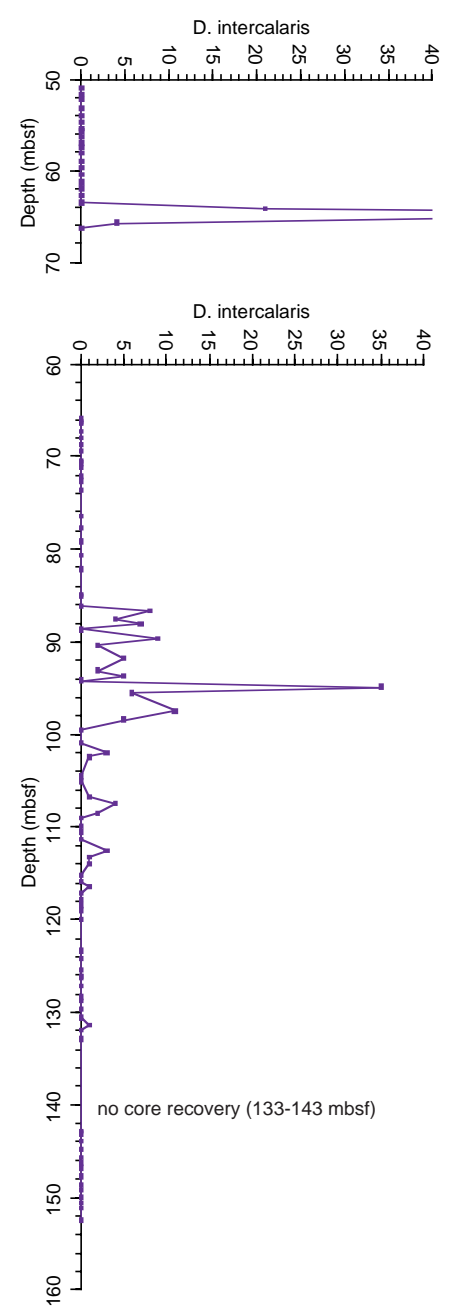

D. tamalis

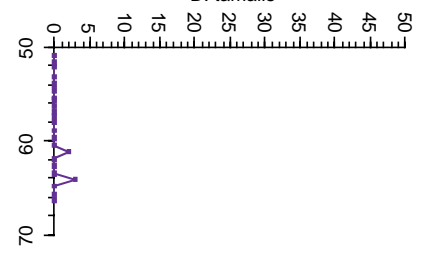

D. tamalis

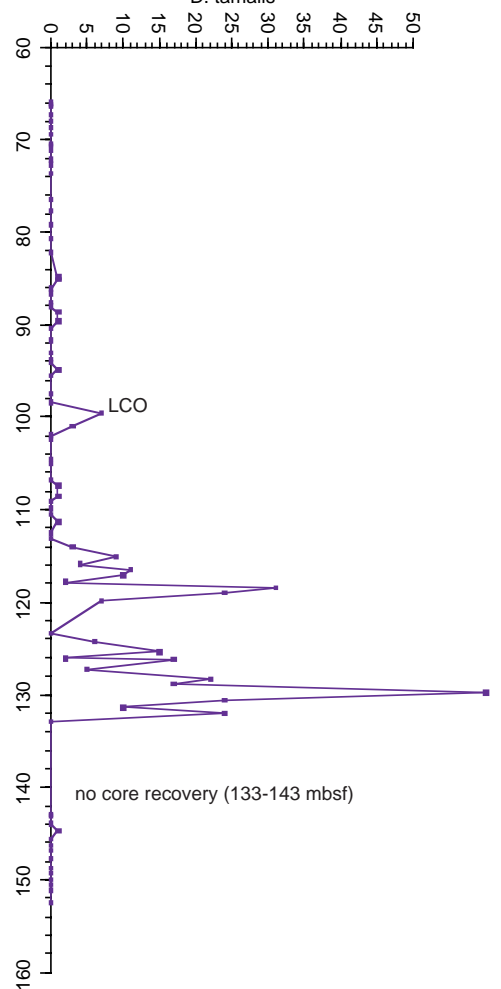

D. variabilis

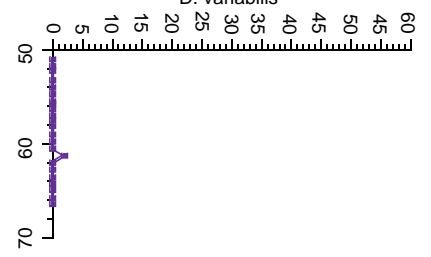

D. variabilis

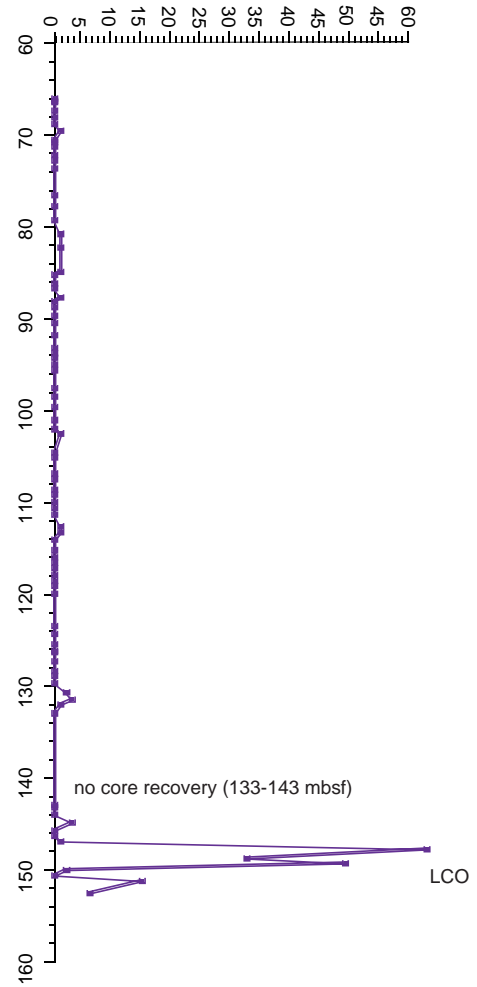

Figure 6 (continued).

Table 1. Calcareous nannofossil datums.

\begin{tabular}{lc}
\hline \multicolumn{1}{c}{ Biostratigraphic event } & $\begin{array}{c}\text { Age } \\
\text { (reference) }\end{array}$ \\
\hline FAD E. huxleyi & $0.26(\mathrm{a})$ \\
LAD P. lacunosa & $0.46(\mathrm{a})$ \\
FAD Gephyrocapsa sp. 3 & $0.98(\mathrm{~b})$ \\
LAD large Gephyrocapsa & $1.22(\mathrm{~b})$ \\
FAD large Gephyrocapsa & $1.47(\mathrm{~b})$ \\
LAD C. macintyrei & $1.59(\mathrm{~b})$ \\
FAD G. oceanica & $1.75(\mathrm{c})$ \\
FAD D. brouweri & $1.99(\mathrm{c})$ \\
LAD D. pentaradiatus & $2.51(\mathrm{c})$ \\
LAD D. tamalis & $2.63(\mathrm{~d})$ \\
LCO D. tamalis & $2.82(\mathrm{c})$ \\
top of paracme D. pentaradiatus & $3.56(\mathrm{c})$ \\
LO Sphenolithus abies/neoabies & $3.73(\mathrm{c})$ \\
LO R. pseudoumbilicus & $3.85(\mathrm{c})$ \\
base of paracme D.pentaradiatus & $3.90(\mathrm{c})$ \\
FCO D. asymmetricus & $4.11(\mathrm{c})$ \\
\hline
\end{tabular}

Notes: FAD = first appearance datum, FCO = first common occurrence, $\mathrm{LAD}=$ last appearance datum, LCO = last common occurrence. References: (a) $=$ Rio et al., 1990; (b) = Sprovieri, 1993 (using Cande and Kent [1992] time scale); (c) = Sprovieri, 1993 (using Hilgen [1991] time scale); (d) = Wei, 1993.

967C-7H-5, 53-54 cm (63.53 mbsf). The final sample studied from Hole 967C (Sample 160-967C-7H-7, 35-36 cm) remains in Zone MNN 17-16b and is typified by a predominance of $D$. brouweri and $D$. pentaradiatus coincident with a reduced number of $D$. surculus and $D$. intercalaris specimens.

\section{Hole 967A}

Of the three holes drilled through Holocene to Pliocene aged sediments at Site 967, Hole 967A was the deepest. Pleistocene and Pliocene nannofossil oozes and calcareous oozes were recovered from 0-138 mbsf. Sampling for postcruise nannofossil analysis of Hole 967A began just above the interval interpreted to be equivalent to the most basal section sampled in Hole 967C. By using extended sections from both holes, an attempt was made to create a composite geologic section that contains Pleistocene and uppermost Pliocene material from Hole 967C and uppermost Pliocene through the most basal Pliocene in Hole 967A. Abundance patterns for species studied from Hole 967A are shown in Figure 4C.

The shallowest samples from Hole 967A were collected from Sample 160-967A-8H-1, 46-47 cm (66.76-66.77 mbsf). This sample contains a discoaster assemblage that is comprised of $98 \% \mathrm{D}$. brouweri. Excluding a minor percentage of other discoasters interpreted as reworked, $D$. brouweri and $D$. triradiatus were the only the discoasters in the interval from Sample 160-967A-8H-4, 46-47 cm (71.26-71.27 mbsf). Based on this discoaster assemblage, samples from 66.76 through $71.27 \mathrm{mbsf}$ are placed in Zone MNN 18. The following $3 \mathrm{~m}$ (71.27-74.26 mbsf), which is represented by only 3 samples, are problematic because discoasters are rare to absent. The paucity of discoasters from 71.27-74.26 mbsf hinders the placement of this interval in a zone. The interval is tentatively grouped with the overlying samples and assigned to Zone MNN 18. 
In Sample 160-967A-8H-6, 46-47 cm (74.26-74.27 mbsf), immediately below the interval devoid of discoasters, a distinct assemblage change characterized by an abundance of $D$. pentaradiatus is recognized. Specimens of D. tamalis, D. surculus, and D. asymmetricus are also first observed downhole; however, each of these species account for only $1 \%$ of the discoaster population and are considered reworked. Based on the presence of $D$. pentaradiatus, this sample is interpreted to be within Zone MNN 17-16b. The next sample downhole, Sample 160-967A-8H-6, 110-111 cm (74.90-74.91 mbsf) contains the LAD of $D$. intercalaris followed by the LAD of D. surculus in Sample 160-967A-8H-7, 46-47 cm (75.76-75.77 mbsf). The stratigraphic relationship of $D$. surculus and D. intercalaris is slightly different in Hole 967A than in the equivalent interval from Hole 966D, where the LADs of D. surculus and D. intercalaris appear coeval.

The appearance of D. tamalis, in abundances greater than $2 \%$ of the discoaster assemblage, occurs in Sample 160-967A-8H-9H-3, $110-111 \mathrm{~cm}(79.90-79.91 \mathrm{mbsf})$ and marks the top of Zone MNN 16a. Discoaster tamalis remains low in abundance downhole until Sample 160-967A-10H-4, 11-112 cm (90.91-90.92 mbsf), where an increase spanning $\sim 7 \mathrm{~m}$ is observed. In the samples within Zone MNN 16a that precede the increase in $D$. tamalis, the population of $D$. pentaradiatus fluctuates up to $78 \%$ relative to the overall discoaster population. Additionally, in the interval that shows a decline of $D$. pentaradiatus, an increase in $D$. brouweri and D. surculus is observed. Other discoaster species, such as D. tamalis, D. triradiatus, $D$. intercalaris, and D. asymmetricus show little change in this interval.

In Sample 160-967A-11H-2, 123-124 cm (97.53-97.54 mbsf), D. pentaradiatus is absent from the assemblage. The interval devoid of D. pentaradiatus continues for $7 \mathrm{~m}$ downhole and is interpreted to be the paracme zone. The typical discoaster assemblage within the uppermost samples of the paracme zone consists of D. brouweri, $D$. intercalaris, and D. asymmetricus. In the lowermost portion of the paracme zone, $D$. surculus predominates the discoaster assemblage with a lesser contribution from $D$. brouweri.

Also within the paracme zone, two nondiscoaster nannofossil datums are recognized. In Sample 160-967A-10H-4, 110-111 cm (100.40-100.41 mbsf) the LAD of Sphenolithus abies/neoabies is observed. In Sample 160-967A-11H-6, 47-48 cm (102.77-102.78 mbsf), the LAD of $R$. pseudoumbilicus is observed. The LAD of $R$. pseudoumbilicus also denotes the top of Zone MNN 15-14. The base of Zone MNN 15-14 is recognized at Sample 160-967A-11H-7, 38$39 \mathrm{~cm}$ (104.18-104.19 mbsf) by the FAD of D. asymmetricus.

Below the FAD of $D$. asymmetricus the zonal interpretations are unclear. The LAD of A. tricorniculatus first appears downhole in Sample 160-967A-12H-1, 110-111 cm (105.40-105.41 mbsf); however, the FAD of $A$. delicatus, which should occur stratigraphically uphole from A. tricorniculatus, is also observed in this sample. Because of this relationship, Samples from 105.40-118.10 are placed into a combined Zone MNN 13/MNN 12. Sample 160-967A-13H-3, $129-130 \mathrm{~cm}$ (118.09-118.10 mbsf) was the deepest sample analyzed in this study. For a biostratigraphic discussion of lowermost Pliocene (Zanclean stage) nannofossils collected from the interval below 118.10 mbsf, see Castradori, Chap. 9, this volume.

\section{Hole 968A}

Site 968 was located on the Cyprus side of the subduction zone (Fig. 1). Sediments recovered from Hole 968A showed significant quantities of reworked nannofossils, foraminifers, and silt-sized particles likely transported downslope from the Cyprus margin. Abundance patterns for selected species studied from Hole 968A are shown in Figures 5B and 6B.

From Sample 160-968A-1H-1, 27-28 cm (0.27-0.28 mbsf) through Sample 160-968A-1H-5, 104-105 cm (7.04-7.05 mbsf), $E$. huxleyi was observed, which places these samples into upper Pleisto- cene Zone MNN 21. Confirmation of the E. huxleyi datum was not conducted using the SEM for samples collected from Hole 968A. Owing to an abundance of reworked taxa and calcite fragments within this zone, the E. huxleyi acme subzone was not identified in Hole 968A. A semiquantitative evaluation of the accompanying assemblage shows that G. oceanica is rare or absent in Zone MNN 21. The lower boundary Zone MNN 21 is marked by a sharp decline in $E$. huxleyi at 7.04 mbsf.

The interval from Sample 160-968A-1H-6, 43-44 cm (7.93-7.94 mbsf) through Sample 160-968A-3H-3, 49-50 cm (21.99-22.00 mbsf) is characterized by the absence of both E. huxleyi and in situ specimens of middle Pleistocene marker, $P$. lacunosa. The accompanying assemblage is typified by an abundance of small gephyrocapsids and a $G$. oceanica content that is rare or absent in the uppermost portion of this zone, but fluctuates from $3 \%-44 \%$ of the total nannofossil assemblage in the middle and lower portions of the zone. Based on this assemblage, the samples from 7.93-22.00 mbsf are placed into Zone MNN 20. As were observed in samples uphole, reworked microfossils and silt-sized carbonate fragments are common.

In Sample 160-968A-3H-3, 121-122 cm (22.71-22.72 mbsf), $P$. lacunosa is first observed downhole in concentrations that are equal to or greater than $1 \%$ of the total nannofossil population. Although $P$. lacunosa was observed uphole, all counts were below $1 \%$. In the initial few samples below this boundary, P. lacunosa fluctuates in abundance above and below the $1 \%$ threshold concentration.

In Sample 160-968A-4H-1, 129-130 cm (29.29-29.30 mbsf), Gephyrocapsa sp. 3 is first observed downhole. Gephyrocapsa sp. 3 is part of the assemblage for $2.74 \mathrm{~m}$ downhole through Sample 160968A-4H-3, 103-104 cm (32.03-32.04 mbsf), where its FAD is recognized as the lower boundary for Zone MNN $19 f$.

In the interval from Sample 160-968A-4H-4, 135-136 cm (33.85-33.86 mbsf) through Sample 160-968A-4H-7, 18-19 cm (37.18-37.19) mbsf, the nannofossil assemblage is typified by an abundance of small gephyrocapsa in the absence of all gephyrocapsa larger than $4.0 \mu \mathrm{m}$. Therefore, this interval is assigned to Zone MNN $19 \mathrm{e}$.

Large Gephyrocapsa $(>5.5 \mu \mathrm{m})$ first enters the assemblage downhole in Sample 160-968A-5H-1, 18-19 cm (37.68-37.69 mbsf), which marks the top of Zone MNN 19d. The base of the zone is evidenced by the FAD of large Gephyrocapsa $(>5.5 \mu \mathrm{m})$, in Sample 160-968A-5H-CC, 17-18 cm (47.33-47.34 mbsf).

Samples 160-968A-6H-1, 30-31 cm (47.30-47.31 mbsf) through $6 \mathrm{H}-1,123-124 \mathrm{~cm}(48.23-48.24 \mathrm{mbsf})$ are characterized by the absence of large Gephyrocapsa $(>5.5 \mu \mathrm{m})$ and $C$. macintyrei. This interval is assigned to Zone MNN 19c.

Calcidiscus macintyrei becomes a consistent part of the nannofossil assemblage in Sample 160-968A-6H-2, 29-30 cm (48.79-48.80 mbsf), which marks the top of Zone $19 \mathrm{~b}$. The base of Zone $19 \mathrm{~b}$ is recognized in Sample 160-968A-6H-4, 122-123 cm (52.72-52.73 mbsf), where the FAD of $G$. oceanica is observed.

The interval from Sample 160-968A-6H-5, 23-24 cm (53.2353.24 mbsf) through Sample 160-968A-7H-6, 129-130 cm (65.29$65.30 \mathrm{mbsf}$ ) is typified by the absence of $G$. oceanica. Although $D$. brouweri was observed in this interval, several other species of discoaster were also observed. Because fewer than 25 total discoasters were observed per traverse of each slide $\left(\sim 9 \mathrm{~mm}^{2}\right)$ in the interval from 53.23-65.30 mbsf, and the proportion of D. brouweri observed relative to the other discoasters was small, all of the discoasters in this interval were interpreted as reworked. Because of the absence of both G. oceanica and in situ discoasters, the interval from Sample 160968A-6H-5, 23-24 cm (53.23-53.24 mbsf) through Sample 160968A-7H-6, 129-130 cm (65.29-65.30 mbsf) is assigned to uppermost Pliocene Zone MNN 19a.

The LAD of $D$. brouweri (top of Zone MNN 18) was interpreted to be in Sample 160-968A-7H-7, 48-49 cm (65.98-65.99 mbsf). The discoaster assemblage within MNN 18 includes D. brouweri and $D$. triradiatus in concentrations that fluctuate significantly. Many sam- 
ples in this interval do not contain discoasters or contain less than 100 discoasters per count. Reworked species and calcite fragments also fluctuate in this interval.

The foraminiferal analysis conducted aboard ship does not agree with the stratigraphic interpretations from calcareous nannofossils for the interval interpreted to be within Zone MNN 19a (Emeis, Robertson, Richter, et al., 1996). Based on the recognition of the FAD Globorotalia inflata in Sample 160-968A-6H-CC, shipboard foraminiferal interpretations show an unconformity between Samples 160-968A-6H-CC (56.50-56.51) and Sample 7H-3, 79-81 (60.2260.23 ). Foraminiferal interpretations indicate that sediments representing approximately $0.76 \mathrm{~m}$.y. from the late Pliocene (equivalent to most of MNN 19a and some of MNN 18) are missing from Hole 968A.

Because the nannofossil data studied aboard ship and the results of this study both show that $D$. brouweri is absent from the samples immediately below the purported unconformity, no obvious evidence for an unconformity can be provided by the nannofossil data. Within the interval that the foraminiferal interpretations show to be equivalent to Zone MNN 18, six consecutive samples from a combination of shipboard and shore-based analyses are devoid of D. brouweri and $D$. triradiatus. Although quantitative abundance patterns for D. brouweri and $D$. triradiatus from the Western Mediterranean (Rio et al., 1990) show samples in the upper portions of Zone MNN 18 that are devoid of discoasters, it is unlikely that six consecutive samples that span $8.8 \mathrm{~m}$ in Hole 968A would be devoid of the marker species for MNN 18. Furthermore, neither the studies of Rio et al. (1990) and Driever (1988), nor data from the other holes at Leg 160 sites show extended intervals within Zone MNN 18 that are barren of discoasters. With the lack of other correlatable intervals within Zone MNN 18 to support an unconformity interpretation, a more conservative interpretation suggests that the samples devoid of $D$. brouweri are within Zone MNN 19a and that the FAD of G. inflata was observed too high stratigraphically in Hole 968A.

The LAD of D. pentaradiatus is observed in Sample 160-968A9H-7, 35-36 cm (84.85-84.86 mbsf). However, the samples preceding the LAD of $D$. pentaradiatus contain rare numbers of discoasters that include $D$. pentaradiatus. The placement of the LAD of $D$. pentaradiatus at Sample 160-968A-9H-7, 35-36 cm (84.85-84.86 mbsf) is, therefore, based on the interpretation that all occurrences of $D$. pentaradiatus uphole are reworked. Samples below Sample 160968A-9H-7, 35-36 cm (84.85-84.86 mbsf) are in Zone MNN 17$16 \mathrm{~b}$. The LADs of $D$. surculus and $D$. intercalaris are also observed in Zone MNN 17-16b, two samples below where the LAD of $D$. pentaradiatus is placed. The placement of the LADs of $D$. pentaradiatus, D. surculus, and D. intercalaris in Hole 968A is consistent with the interpretations from Holes 966D and 967A. The base of Zone MNN $17-16 \mathrm{~b}$ is placed in Sample 160-968A-11X-3, 91-92 cm (98.41$98.42 \mathrm{mbsf}$ ), the last sample above the LAD of D. tamalis.

The top of Zone MNN 16c is placed in Sample 160-968A-11X-4, $52-53 \mathrm{~cm}$ (99.52-99.53 mbsf) where Discoaster tamalis is observed in abundances slightly greater than $2 \%$ of the total discoaster assemblage. Discoaster tamalis remains a consistent but minor constituent of the total discoaster assemblage until Sample 160-968A-13X-2, $129-130 \mathrm{~cm}$ (116.49-116.50 mbsf), where abundances of $D$. tamalis increase to $11 \%$ of the discoaster population. Below this point, D. $t a-$ malis fluctuates from $2 \%$ to $60 \%$. Similar to the assemblage changes observed in Hole $967 \mathrm{~A}$, the population of $D$. pentaradiatus shows a significant drop in abundance several meters above the $D$. tamalis increase at $116.50 \mathrm{mbsf}$. Although the magnitude of the decrease is smaller than that observed in 967A, the coincident increase in abundance of $D$. brouweri and $D$. surculus relative to the other discoasters is similar to what was observed in Hole 967A.

Another significant change in the assemblage occurs in Sample 160-968A-14X-5, 35-36 cm (129.65-129.66 mbsf), where the top of the $D$. pentaradiatus paracme event is observed. The interval devoid of D. pentaradiatus continues through Sample 160-968A-14X-6,
$117-118 \mathrm{~cm}$ (131.97-131.98 mbsf), which indicate that these samples are within the middle to lower part of Zone MNN 16a. Sample 160-968A-14X-6, 117-118 cm (131.97-131.98 mbsf) also contains the lowermost occurrence of $D$. tamalis and the FAD of P. lacunosa.

Following a 10-m interval of no recovery in Core 160-968A-15X, another significant assemblage change occurs in Sample 160-968A$16 \mathrm{X}-1,25-26 \mathrm{~cm}$ (143.15-143.16 mbsf). The first downhole occurrences of Sphenolithus abies/neoabies, $R$. pseudoumbilicus, and A. delicatus are observed concomitant to the re-emergence of $D$. pentaradiatus. Collectively, the presence of these events in the same sample indicates that sediments from the middle of Zone MNN 16a overlie sediments from the base of Zone MNN 15-14. Because of the lack of core recovery in Core 968A-15X, it is difficult to determine if an unconformity exists between 131.90 and $142.90 \mathrm{mbsf}$ or if the missing core interval contains the lowermost portion of Zone MNN 16a and the uppermost portion of Zone MNN 15/14.

The FAD of D. asymmetricus is observed at Sample 160-968A16X-1, 104-105 cm (143.94-143.95 mbsf), two samples below the base of the unrecovered interval in Core 968A-15X. The FAD of $D$. asymmetricus marks the base of Zone MNN 15-14.

From Sample 160-968A-16X-2, 37-38 cm (144.77-144.78 mbsf) through Sample 160-968A-16X-5, 35-36 cm (149.25-149.26 mbsf), Zone MNN 13 is recognized. This zone is defined by the absence of both $D$. asymmetricus and A. tricorniculatus. Within this zone, a significant increase in D. variabilis occurs at Sample 160-968A-16X-4, 33-34 cm (147.73-147.74 mbsf). A similar increase is observed in Hole 967A.

The presence of A. tricorniculatus in Sample 160-968A-16X-5, $108-109 \mathrm{~cm}$ (149.98-149.99 mbsf) indicates that this sample marks the beginning of Zone MNN 12. This zone continues through Sample 160-968A-17X-2, 86-87 cm (154.56-154.57 mbsf). Below 154.57 mbsf a paucity of nannofossils prevented the biostratigraphic determination of additional samples.

\section{STRATIGRAPHIC DISCUSSION Significance of Unconformities}

As expected within a tectonically active environment, the sedimentary record across the Eratosthenes transect shows a discontinuous geologic sequence from the Holocene through early Pliocene time at all sites except Site 967. Site 965, which currently lies on the northern flank of the subducting seamount, has the least continuous geologic record of the Eratosthenes sites. One significant unconformity, which likely included the Pliocene/Pleistocene boundary $(0.92$ Ma to $0.25 \mathrm{Ma}$ ) was interpreted at Site 965 . Three additional minor unconformities are also interpreted at Site 965: (1) missing sediments that spanned an interval up to $0.2 \mathrm{~m}$.y. of the early to middle Pleistocene, (2) missing interval that includes up to 0.35 m.y. of upper Pliocene to lower Pliocene sediments, and (3) missing interval of up to 0.4 m.y. of lower Pliocene sediments.

The sediments from Site 966, located on the crest of the seamount, also contain unconformities. An interval equivalent to a portion of the prominent unconformity in Hole 965A occurs across lower Pleistocene sediments and represents a missing time interval that ranges from $\sim 0.16$ to $0.60 \mathrm{Ma}$. A second unconformity is interpreted in lower Pliocene sediments and spans an estimated interval up to $0.10 \mathrm{Ma}$.

Site 968 appears to be continuous through the Pleistocene and upper Pliocene intervals, but shows a missing interval in the lower Pliocene that represents $\sim 0.33 \mathrm{Ma}$.

The presence of unconformities from the lower Pliocene sediments of three of the holes along the Eratosthenes transect suggests that significant tectonic movement occurred in the seamount region near 3.5 Ma. Because no evidence of an unconformity is reflected in lower Pliocene sediments from Site 967, it is suggested that the mechanism that resulted in the unconformities at the other sites was focused locally and likely represented erosion along uplifted faults 
blocks. Likewise, the additional hiatuses observed in the Pleistocene sediments at Sites 965 and 966 probably reflect continued faulting of these areas as the southernmost portions of the seamount began collapsing during subduction.

\section{Comparison of Leg 160 Abundance Patterns to Other Mediterranean Geologic Sections}

Conventional biostratigraphic zonations rely on datums that may be spaced more than 1-3 m.y. apart. The recognition of secondary features of the assemblage, represented in the species abundance shifts, aid in determining the location of a sample between the conventional zonal markers. By using the secondary markers, unconformities within a zone may be identified.

Because the geologic sections from most of the sites along the Eratosthenes Seamount transect were incomplete (except Site 967), comparison of the nannofossil abundance patterns with other geologic sections in the Mediterranean is tenuous. However, some significant events are apparent in abundance patterns from both Leg 160 data and Western and Central Mediterranean studies of Rio et al., 1990; Channell et al., 1992; Castradori, 1993; and Driever, 1988.

As was mentioned previously, Site 967 provided the most complete geologic section from the Eratosthenes transect to serve as the reference section for abundance characteristics in the Eastern Mediterranean. Compared to the abundance patterns presented by Rio et al. (1990) for the Tyrrhenian Sea, the species abundance patterns from Site 967 were similar. All of the significant species abundance shifts detailed by Rio et al. (1990) including LADs and FADs of all marker species, were observed at Site 967 . In addition, three secondary features of the abundance curves for the discoasters monitored in both studies can be used for biostratigraphic correlation.

\section{$L A D$ of Discoaster surculus}

Abundance curves for $D$. surculus from this study show that the LAD of $D$. surculus is consistently below the LAD of $D$. pentaradiatus. A comparison of abundance curves for the Singa section (Driever, 1988) and Tyrrhenian Sea Site 653 (Rio et al., 1990) shows a similar relationship for the LADs of D. pentaradiatus and D. surculus. In the Monte San Nicola section (Driever, 1988; Channell et al., 1993), the relationship of the LADs of $D$. pentaradiatus and $D$. surculus is difficult to determine because of increased terrigenous input and reworking. However, depending on the abundance criteria used to determine reworked specimens from those specimens interpreted to be within the range of $D$. surculus, the data from the Monte San Nicola section could also support an interpretation that the LAD of $D$. surculus is an older event in the Mediterranean than the LAD of $D$. pentaradiatus. The LAD of $D$. surculus is considered an almost synchronous event that globally occurs in oxygen isotope Stage 99-101 (Wei, 1993). Conversely, D. pentaradiatus is considered to be diachronous (Wei, 1993). In the Mediterranean, the LAD of $D$. pentaradiatus occurs consistently in Stages 99-100, whereas the LAD of $D$. surculus is observed in Stages 100-101 (Vergnaud-Grazzini et al., 1994).

The extra-Mediterranean zonation schemes of Okada and Bukry (1980) and Martini (1971) suggest that the LADs of D. pentaradiatus and $D$. surculus be used as zonal boundaries, although other studies have suggested that these events are too close together stratigraphically in Mediterranean geologic sections to warrant this usage (Müller, 1978; Ellis and Lohman, 1979; Raffi and Rio, 1979). There is sufficient data, however, to indicate that the LAD of $D$. surculus is a slightly older event than the LAD of $D$. pentaradiatus in the Mediterranean. Because these two events appear consistent and can be differentiated in studies that provide sufficient sample spacing, the events should be used to determine if the top of the $D$. pentaradiatus Zone is present at sites throughout the Mediterranean.

\section{Acmes of Discoaster asymmetricus and Discoaster tamalis}

In the upper Pliocene, just above the top of the $D$. pentaradiatus paracme, D. tamalis and D. asymmetricus display abundance increases at the Eratosthenes sites. The coeval acmes of D. asymmetricus and $D$. tamalis in the Mediterranean were first cited by Driever (1988) based on sections from Sicily, Calabria, and Crete. Driever (1988) used the top of the acme of D. tamalis and D. asymmetricus as a datum. Acmes of $D$. tamalis and D. asymmetricus are also evident at approximately the same interval in the Tyrrhenian Sea Site 653 (Rio et al., 1990). Because, the highest abundance peaks do not always correlate well among geographic region of the Mediterranean, only the top of the acme intervals for $D$. tamalis and $D$. asymmetricus should be considered as a datum. This datum would also be considered a secondary marker to help determine if some of a geologic section is missing between the top of the $D$. pentaradiatus paracme and the LAD of $D$. tamalis.

The LCO of $D$. tamalis is calibrated to oxygen isotope Stage 115 by Sprovieri (1993). Although an acceptable definition for the top of the acmes of $D$. tamalis and $D$. asymmetricus has not been established nor calibrated to an oxygen isotope stage, it appears that the acmes of $D$. tamalis and $D$. asymmetricus occur below oxygen isotope Stage 115 and thus older than 2.82 Ma.

\section{LCO of Discoaster variabilis}

Another prominent biostratigraphic event displayed in Leg 160 sites and other Mediterranean geologic sections is the abundance shift of $D$. variabilis within Zone MNN 13. The biostratigraphy of lower Pliocene sediments is problematic in the Mediterranean because the nannofossil datums used to subdivide the lower Pliocene in extra-Mediterranean zonation schemes are rare in the Mediterranean (such as ceratoliths and amauroliths). Driever (1988) concluded that despite the presence of significant reworked microfossils, a distinguishable shift in abundance of $D$. variabilis was recognizable in Mediterranean sections. The sharp downhole increase in abundance of $D$. variabilis is easily recognized below the LADs of $D$. tamalis and $D$. asymmetricus at the sites from the Eratosthenes transect (Figs. $4,6 \mathrm{~B}$ ) and can be used as a biostratigraphic marker for the lower Pliocene. The method used to quantify the abundance of $D$. variabilis at Leg 160 sites, which involved counts of D. variabilis relative to 100 total discoasters, was one of the methods used to quantify $D$. variabilis for Tyrrhenian Sea Site 653. The apparent synchroneity of the abundance increase of $D$. variabilis in the early Pliocene of both the Tyrrhenian Sea (Rio et al., 1990) and this study suggests that the LCO of $D$. variabilis could be used in other Mediterranean geologic sections for subdividing the lower Pliocene.

\section{CONCLUSIONS}

Quantitative methods used to document the abundance patterns of selected calcareous nannofossil species from four sites in the Eratosthenes Seamount region of the Eastern Mediterranean show many similarities to the abundance patterns of the same species studied in the Western and Central Mediterranean. Through the use of the Neogene zonation scheme and quantitative methods for documenting the abundance of selected species proposed by Rio et al. (1990), a highresolution biostratigraphy for the Eastern Mediterranean has been established in this study.

Although all of the sites drilled at Eratosthenes Seamount appeared affected by faulting associated with subduction of the seamount beneath the Anatolian subplate at Cyprus, Holes 967A and 967C provided a continuous geologic reference section for the Eastern Mediterranean that spanned from the lower Pliocene through Holocene. Comparison of the Eratosthenes reference section from 
Holes 967A and 967C with geologic sections in the Tyrrhenian Sea (Rio et al., 1990), Sicily (Channell et al., 1992; Driever, 1988), and Crete (Driever, 1988) show many similarities in the characteristics of species abundance patterns, validating the utility of the Rio et al. (1990) zonation scheme for use in the Eastern Mediterranean.

In addition to the primary biostratigraphic markers proposed by Rio et al. (1990), three secondary features of the abundance curves of discoasters are proposed for biostratigraphic correlation in the Mediterranean: (1) the LAD of $D$. surculus has been documented in several geologic sections as an event older than the LAD of $D$. pentaradiatus in the Mediterranean and can be effectively used in geologic sections that have sufficient sample spacing and moderate to little reworking; (2) abundance peaks for D. asymmetricus and D. tamalis just above the paracme of $D$. pentaradiatus can be used to correlate within upper Pliocene Zone MNN16a in the Eastern Mediterranean; (3) the LAD of D. variabilis is within Zone MNN 13 and is easily recognized at the sites from the Eratosthenes transect and can likely be used as a consistent biostratigraphic marker for the lower Pliocene sediments throughout the Mediterranean.

Several unconformities were recognized at the Eratosthenes sites. Unconformities likely the result of local faulting associated with Pleistocene tectonic movement of the subducting Eratosthenes Seamount were present in the middle and lower Pleistocene within Holes 965A and 966D. Unconformities likely represent the Pleistocene/ Pliocene boundary in Holes 965A and 966D. Another prominent unconformity was also recognized in lower Pliocene sediments from Holes 965A, 966D, and 968A, which suggests that increased uplift and faulting occurred at approximately $3.5 \mathrm{Ma}$.

\section{ACKNOWLEDGMENTS}

I thank Dr. Sherwood Wise, Jr. of Florida State University for encouragement and technical support during this project. I also gratefully acknowledge Ignacio Pujana and the Geosciences Department at the University of Texas at Dallas for assistance in conducting the scanning electron microscope portion of this study. I am grateful to the reviewers for constructive suggestions during the revision of this manuscript. This work was supported by a USSP Grant \#160F000210 awarded to T. Scott Staerker.

\section{REFERENCES}

Backman, J., and Shackleton, N.J., 1983. Quantitative biochronology of Pliocene and early Pleistocene calcareous nannofossils from the Atlantic, Indian and Pacific oceans. Mar. Micropaleontol., 8:141-170.

Berggren, W.A., Kent, D.V., Swisher, C.C., III, and Aubry, M.-P., 1995. A revised Cenozoic geochronology and chronostratigraphy. In Berggren, W.A., Kent, D.V., Aubry, M.-P., and Hardenbol, J. (Eds.), Geochronology, Time Scales and Global Stratigraphic Correlation. Spec. Publ.Soc. Econ. Paleontol. Mineral., 54:129-212.

Boudreaux, J.E., and Hay, W.W., 1969. Calcareous nannoplankton and biostratigraphy of the late Pliocene-Pleistocene-Recent sediments in the submarex cores. Rev. Esp. Micropaleontol., 1:249-292.

Bukry, D., 1973. Low-latitude coccolith biostratigraphic zonation. In Edgar, N.T., Saunders, J.B., et al., Init. Repts. DSDP, 15: Washington (U.S. Govt. Printing Office), 685-703.

Bukry, D., and Bramlette, M.N., 1969. Some new and stratigraphically useful calcareous nannofossils of the Cenozoic. Tulane Stud. Geol. Paleontol., 7:131-142.

Cande, S.C., and Kent, D.V., 1992. A new geomagnetic polarity time scale for the Late Cretaceous and Cenozoic. J. Geophys. Res., 97:1391713951.

1995. Revised calibration of the geomagnetic polarity timescale for the Late Cretaceous and Cenozoic. J. Geophys. Res., 100:6093-6095.

Castradori, D., 1993. Calcareous nannofossil biostratigraphy and biochronology in eastern Mediterranean deep-sea cores. Riv. Ital. Paleontol. Stratigr., 99:107-126.
Channell, J.E.T., Di Stefano, E., and Sprovieri, R., 1992. Calcareous plankton biostratigraphy, magnetostratigraphy and paleoclimatic history of the Plio-Pleistocene Monte S. Nicola section (Southern Sicily). Boll. Soc. Paleontol. Ital., 31:351-382.

Driever, B.W.M., 1981. A quantitative study of Pliocene associations of Discoaster from the Mediterranean. Proc. K. Ned. Akad. Wet., 84:437-455.

, 1988. Calcareous nannofossil biostratigraphy and paleoenvironmental interpretation of the Mediterranean Pliocene. Utrecht Micropalaeontol. Bull., 36:1-245.

Duplessy, J.-C., Moyes, J., Pujol, C., Pujos-Lamy, A., and Reyss, J.L., 1975. Stratigraphie des dépots quaternaires d'une carotte prelevée au N.E. des Acores. C.R. Acad. Sci. Ser. 2, 281D:1971-1974.

Ellis, C.H., and Lohman, W.H., 1979. Neogene calcareous nannoplankton biostratigraphy in eastern Mediterranean deep-sea sediments. Mar. Micropaleontol., 4:61-84.

Emeis, K.-C., Robertson, A.H.F., Richter, C., et al., 1996. Proc. ODP, Init. Repts., 160: College Station, TX (Ocean Drilling Program).

Gartner, S., 1967. Calcareous nannofossils from Neogene of Trinidad, Jamaica, and Gulf of Mexico. Univ. Kansas Paleontol. Contrib., 29:1-7. , 1969. Correlation of Neogene planktonic foraminifer and calcareous nannofossil zones. Trans. Gulf Coast Assoc. Geol. Soc., 19:585-599. , 1972. Late Pleistocene calcareous nannofossils in the Caribbean and their interoceanic correlation. Palaeogeogr., Palaeoclimatol., Palaeoecol., 12:169-191.

, 1977. Calcareous nannofossil biostratigraphy and revised zonation of the Pleistocene. Mar. Micropaleontol., 2:1-25.

Gartner, S., and Bukry, D., 1975. Morphology and phylogeny of the coccolithophycean family Ceratolithaceae. J. Res. U.S. Geol. Surv., 3:451-465.

Hay, W.W., Mohler, H.P., Roth, P.H., Schmidt, R.R., and Boudreaux, J.E., 1967. Calcareous nannoplankton zonation of the Cenozoic of the Gulf Coast and Caribbean-Antillean area and transoceanic correlation. Trans. Gulf Coast Assoc. Geol. Soc., 17:428-480.

Hilgen, F.J., 1991. Extension of the astronomically calibrated (polarity) time scale to the Miocene/Pliocene boundary. Earth Planet. Sci. Lett., 107:349-368.

Kamptner, E., 1943. Zur Revision der Coccolithineen-Spezies Pontosphaera huxleyi Lohman. Akad. Wiss. Wien, Math.-Naturwiss. Kl., Anz., 80:4349.

Kamptner, E., 1963. Coccolithineen-Skelettreste aus Tiefseeablagerungen des Pazifischen Ozeans. Ann. Naturhist. Mus. Wien, 66:139-204.

Loeblich, A.R., and Tappan, H., 1978. The coccolithophorid genus Calcidiscus Kamptner and its synonyms. J. Paleontol., 52:1390-1392.

Martini, E., 1971. Standard Tertiary and Quaternary calcareous nannoplankton zonation. In Farinacci, A. (Ed.), Proc. 2nd Int. Conf. Planktonic Microfossils Roma: Rome (Ed. Tecnosci.), 2:739-785.

Matsuoka, H., and Okada, H., 1989. Quantitative analysis of Quaternary nannoplankton in the subtropical northwestern Pacific Ocean. Mar. Micropaleontol., 14:97-118.

1990. Time-progressive morphometric changes of the genus Gephyrocapsa in the Quaternary sequence of the tropical Indian Ocean, Site 709. In Duncan, R.A., Backman, J., Peterson, L.C., et al., Proc. ODP, Sci. Results, 115: College Station, TX (Ocean Drilling Program), 255270.

McIntyre, A., and McIntyre, R., 1971. Coccolith concentrations and differential solution in oceanic sediments. In Funnel, B.M., and Riedel, W.R. (Eds.), The Micropaleontology of Oceans: London (Cambridge Univ. Press), 253-261.

Müller, C., 1978. Neogene calcareous nannofossils from the Mediterranean-Leg 42A of the Deep Sea Drilling Project. In Hsü, K.J., Montadert, L., et al., Init. Repts DSDP, 42 (Pt. 1): Washington (U.S. Govt. Printing Office), 727-751.

Okada, H., and Bukry, D., 1980. Supplementary modification and introduction of code numbers to the low-latitude coccolith biostratigraphic zonation (Bukry, 1973; 1975). Mar. Micropaleontol., 5:321-325.

Proto Decima, F., and Masotti, C., 1981. The genus Gephyrocapsa (Coccolithophorales) in the Plio-Pleistocene of the Timor Trough. Mem. Sci. Geol., 34:453-464.

Pujos-Lamy, A., 1977a. Emiliania et Gephyrocapsa (Nannoplancton calcaire): biométrie et interet biostratigraphique dans le Pleistocene superieur marin des Acores. Rev. Esp. Micropaleontol., 9:69-84.

Pujos-Lamy, A., 1977b. Essai d'établissement d'une biostratigraphie du nannoplancton calcaire dans le Pleistocène de l'Atlantique Nord-oriental. Boreas, 6:323-331. 
Raffi, I., and Rio, D., 1979. Calcareous nannofossil biostratigraphy of DSDP Site 132-Leg 13 (Tyrrhenian Sea-Western Mediterranean). Riv. Ital. Paleontol. Stratigr., 85:127-172.

Rio, D., 1982. The fossil distribution of coccolithophore genus Gephyrocapsa Kamptner and related Plio-Pleistocene chronostratigraphic problems. In Prell, W.L., Gardner, J.V., et al., Init. Repts. DSDP, 68: Washington (U.S. Govt. Printing Office), 325-343.

Rio, D., Raffi, I., and Villa, G., 1990. Pliocene-Pleistocene calcareous nannofossil distribution patterns in the Western Mediterranean. In Kastens, K.A., Mascle, J., et al., Proc. ODP, Sci. Results, 107: College Station, TX (Ocean Drilling Program), 513-533.

Roth, P.H., and Berger, W.H., 1975. Distribution and dissolution of coccoliths in the south and central Pacific. In Sliter, W.V., Bé, A.W.H., and Berger, W.H. (Eds.), Dissolution of Deep-Sea Carbonates. Spec. Publ. Cushman Found. Foraminiferal Res., 13:87-113.

Samtleben, C., 1978. Pliocene-Pleistocene coccolith assemblages from the Sierra Leone Rise-Site 366, Leg 41. In Lancelot, Y., Seibold, E., et al., Init. Repts. DSDP, 41: Washington (U.S. Govt. Printing Office), 496.

Samtleben, C., 1980. Die Evolution der Coccolithophoriden-Gattung Gephyrocapsa nach Befunden im Atlantik. Palaontol. Z., 54:91-127.

Schmidt, R.R., 1973. A calcareous nannoplankton zonation for upper Miocene-Pliocene deposits from the Southern Aegean area, with a comparison to Mediterranean stratotype localities. Proc. K. Ned. Akad. Wet., Ser. B: Paleontol., Geol., Phys., Chem., 76:287-310.

Shackleton, N.J., Berger, A., and Peltier, W.A., 1990. An alternative astronomical calibration of the lower Pleistocene timescale based on ODP Site 677. Trans. R. Soc. Edinburgh: Earth Sci., 81:251-261.
Sprovieri, R., 1992. Mediterranean Pliocene biochronology: a high resolution record based on quantitative planktonic foraminifera distribution. Riv. Ital. Paleontol. Stratigr., 98:61-100.

, 1993. Pliocene-early Pleistocene astronomically forced planktonic foraminifera abundance fluctuations and chronology of Mediterranean calcareous plankton bio-events. Riv. Ital. Paleontol. Stratigr., 99:371-414.

Thierstein, H.R., Geitzenauer, K., Molfino, B., and Shackleton, N.J., 1977. Global synchroneity of late Quaternary coccolith datum levels: validation by oxygen isotopes. Geology, 5:400-404.

Vergnaud-Grazzini, C., Capotondi, L., and Lourens, L., 1994. A refined Pliocene to early Pleistocene chronostratigraphic frame at ODP Hole 653A (West Mediterranean). Mar. Geol., 117:329-349.

Wei, W., 1993. Calibration of Upper Pliocene-Lower Pleistocene nannofossil events with oxygen isotope stratigraphy. Paleoceanography, 8:85-99.

Zijderveld, J.D.A., Hilgen, F.J., Langereis, C.G., Verhallen, P.J.J.M., and Zachariasse, W.J., 1991. Integrated magnetostratigraphy and biostratigraphy of the upper Pliocene-lower Pleistocene from the Monte Singa and Crotone areas in Calabria (Italy). Earth Planet. Sci. Lett., 107:697-714.

\footnotetext{
Date of initial receipt: 16 January 1997

Date of acceptance: 1 August 1997

Ms 160SR-027
} 


\section{APPENDIX}

\section{TAXONOMIC DISCUSSION}

The biostratigraphic use of nannofossils relies upon the synchronous or near synchronous distribution of species abundance events within the region being studied. Aside from latitudinal differences in nannofossil assemblages, primarily resulting from water temperature, zonation schemes have been established that reflect synchronous events ubiquitous around the globe (Martini, 1971; Okada and Bukry, 1980; and Gartner, 1969). These ubiquitous datums usually correspond to the LAD, FAD, or the acme of diagnostic species. Regionally, variations to the standard zonation schemes reflect differences in nannofossil assemblage patterns within individual basins. Because the Mediterranean region during the Pleistocene and Pliocene contained a water mass largely independent from the Atlantic and Indian Oceans, variations in nannofossil assemblages hinder the use of conventional zonation schemes in Mediterranean geologic sections. To accommodate the assemblage differences between Mediterranean sites and the global standards, several nannofossil zonation schemes have been previously proposed for the Mediterranean (Schmidt, 1973; Müller, 1978; Ellis and Lohman, 1979; Raffi and Rio, 1979; Rio et al., 1990.).

Although species definitions must accompany the holotype, differing species concepts for given taxa may exist among researchers. These differences are given added significance when the morphologic characteristics used to define a given species affect the placement of biozones. To clarify the morphologic concepts of taxa used in this paper, all of the species used for biostratigraphy are briefly discussed. The absolute ages of the datums used in this study, as calibrated to magnetostratigraphic or oxygen isotope standards, are found in Table 1 .

\section{Emiliania huxleyi (Lohmann, 1902) Hay and Mohler in Hay et al. (1967)}

Owing to its small size $(2.5-5 \mu \mathrm{m})$, its propensity for dissolution relative to the coexisting gephyrocapsids (McIntyre and McIntyre, 1971; Roth and Berger, 1975; Thierstein et al., 1977), and the rarity of E. huxleyi near its first occurrence in oxygen isotope Stage 8 (Thierstein et al., 1977), the first occurrence of E. huxleyi is often difficult to determine. Because Leg 160 samples collected from Pleistocene sediments were observed under a magnification of $1200 \times$, the identification of individual specimens of E. huxleyi was not difficult in samples that contained abundant $E$. huxleyi in good to excellent preservation. However, high quantities of silt- and clay-sized carbonate material, coupled with abundant reworking of older taxa observed in the uppermost cores of each hole from this study, prevented the recognition of the acme zone of E. huxleyi.

Although placement of the FAD of E. huxleyi was not hindered by poor preservation, error due to the species' low abundance near its inception is a concern (Thierstein et al., 1977). To approach this problem, counts of 500 total coccoliths were conducted on selected samples using an SEM. Samples above and below the FAD of E. huxleyi as identified in the light microscope were chosen for SEM analysis. Disarticulated coccoliths that possessed the Ibar structure in the distal shield and lacked the central cross-bar indicative of a gephyrocapsid were often observed near the purported FAD. In this study these "questionable" specimens were attributed to E. huxleyi if they were larger than $2 \mu \mathrm{m}$. Specimens smaller than $2 \mu \mathrm{m}$ were interpreted to be broken specimens of Gephyrocapsa protohuxleyi.

\section{Gephyrocapsids}

Numerous researchers have studied the taxonomy and biostratigraphic utility of the genus Gephyrocapsa (Bukry, 1973a; Duplessy et al., 1975; Gartner, 1972, 1977b; Matsuoka and Okada, 1989, 1990; Proto Decima \& Masotti, 1981; Pujos-Lamy, 1977a, b; Rio, 1982; Samtleben, 1978, 1980). A high degree of variability exists in the species concept of this genera, which makes widespread correlation difficult. The two species of Gephyrocapsa most commonly referred to in biostratigraphic literature are G. oceanica (Kamptner, 1943) and G. caribbeanica (Boudreaux and Hay, 1969). Although these two species are widely used as zonal markers for the Pleistocene, a consensus on the size limits and morphologic variation allowed by the holotypes has not been reached. Several of the most recent efforts to clarify the stratigraphic positions of the gephyrocapsids indicate that the group displays a definite timeprogressive change in morphology throughout the late Pliocene and Pleistocene and that the change in size is both consistent and observable in the light microscope. (Matsuoka and Okada, 1989, 1990; Rio, 1982).

Using the biostratigraphic zonation scheme of Rio et al. (1990), the gephyrocapsa group was primarily subdivided according to size, ignoring slight variations in central bar angle, proportions of the central area, and placolith thickness. The lower limit for the medium gephyrocapsids has been placed at $4.0 \mu \mathrm{m}$ and the upper limit at $5.5 \mu \mathrm{m}$. Both G. oceanica and G. caribbeanica fall within the 4.0-5.5 $\mu \mathrm{m}$ size range; therefore, these two species are not distinguished from each other in the Leg 160 study. Gephyrocapsa sp. 3 (Rio, 1982) is a medium-sized gephyrocapsid with the cross-bar positioned nearly parallel to the short axis of the placolith. Small gephyrocapsids are classified here as all forms smaller than $3.5 \mu \mathrm{m}$, and large Gephyrocapsa are species greater than $5.5 \mu \mathrm{m}$ as proposed by Rio et al. (1990).

Because the abundance patterns of the individual Gephyrocapsa species were monitored relative to other gephyrocapsids, the methodology used in this study to quantify the general proportion of individual Gephyrocapsa species was made by counting 500 individual gephyrocapsid specimens of any species, regardless of size. Where significant biostratigraphic events are identified by this "screening" technique, such as the LADs or FADs of Gephyrocapsa sp. 3 or large Gephyrocapsa $(>5.5 \mu \mathrm{m})$, the sample containing these events were analyzed again using the quantitative methods and zonal definitions presented by Rio et al. (1990). The FAD and LAD of Gephyrocapsa sp. 3 and large Gephyrocapsa (>5.5 $\mu \mathrm{m})$ were determined as the point where each species was present above $1 \%$ of the gephyrocapsid assemblage in a count of 100 Gephyrocapsa greater than $4.0 \mu \mathrm{m}$. The quantitative method for determining the FAD of G. oceanica included the count of 300 total coccoliths larger than $3.0 \mu \mathrm{m}$ (Rio et al., 1990).

\section{Pseudoemiliania lacunosa (Kamptner, 1963) Gartner (1969)}

$P$. lacunosa is used biostratigraphically as a LAD zonal boundary in the Pleistocene and as an unconventional FAD in lower Pliocene. Following the definition of Thierstein et al. (1977), the LAD of P. lacunosa is placed at its shift in abundance below $1 \%$ of the total coccolith population in a count of 500 specimens. Using the midpoint of this decrease in the interval between $1 \%$ and zero relative abundance, Thierstein et al. (1977) suggested that the most biostratigraphically useful point for the consistent placement for the LAD occurs just before extinction, which is consistently positioned within oxygen isotope Stage 12 at $0.46 \mathrm{Ma}$. Using cores from the Tyrrhenian Sea, Rio et al. (1990), indicate an abundance signature for P. lacunosa that compares well with that proposed by Thierstein et al. (1977). The placement of the FAD of $P$. lacunosa follows the same quantitative technique as used for identifying the LAD of the species.

\section{Calcidiscus macintyrei (Bukry and Bramlette, 1969) Loeblich and Tappan, 1978}

The distinction between Calcidiscus macintyrei and C. leptoporus in this study is entirely based upon the diameter of the distal shield. A minimum size for C. macintyrei is $11 \mu \mathrm{m}$, as adopted from Rio et al. (1990). Specimens smaller than $11 \mu \mathrm{m}$ are referred to as $C$. leptoporus. The quantitative method for documenting the placement of the LAD of $C$. macintyrei follows that used by Rio et al. (1990), where the LAD is placed at the abundance drop below $1 \%$ in a count of 100 specimens of any Calcidiscus species.

\section{Discoasters}

The quantitative method and zonal definitions used to document the abundance patterns of all discoasters observed in this study followed the method of Rio et al. (1990). The LAD of D. brouweri is placed immediately below the uppermost exit from the overall nannofossil assemblage in the upper Pliocene. The LADs of $D$. pentaradiatus and D. surculus were placed at the drop in species abundance below $1 \%$ in a count of 100 total discoasters. Following the definition of Rio et al. (1990), the LAD of D. tamalis was placed at the decrease in species abundance below $2 \%$ in a 100 specimen discoaster count. The first common occurrence (FCO) of D. asymmetricus is defined as the point where the species increases to greater than $5 \%$ in a count of 100 discoasters. Discoaster surculus, D. intercalaris, and $D$. variabilis were not used as zonal boundaries; however, their respective abundance patterns were documented and are presented in this study as potential secondary biostratigraphic events.

\section{Reticulofenestra pseudoumbilicus (Gartner 1967) Gartner (1969)}

The minimum size for $R$. pseudoumbilicus as used in this study is $7 \mu \mathrm{m}$ (Raffi and Rio, 1979). 
Sphenolithus spp.

Sphenoliths were very abundant through most of the lower Pliocene. The LAD of this genus is used by Rio et al. (1990) as a secondary event for biostratigraphy. Following the method of Rio et al. (1990), the S. abies and $S$. neoabies were not distinguished from each other in this study. The LAD of Sphenolithus spp. was marked by the decrease in abundance below $1 \%$ in a count of 500 total nannofossils.
Amaurolithus tricorniculatus (Gartner 1967) Gartner and Bukry (1975)

Amaurolithus delicatus (Gartner and Bukry 1975)

Species of the amaurolith group occur in very low abundance in the lower Pliocene. To document the abundance of these species, counts of individual amaurolith species were made at a magnification of $500 \times$ over an area $\sim 9$ $\mathrm{mm}^{2}$. 